\title{
Integrating $\mathrm{CO} 2$ capture with electrochemical conversion using amine based capture solvents as electrolytes
}

Elena Pérez-Gallent ( $\square$ elena.perezgallent@tno.nl )

TNO https://orcid.org/0000-0001-7826-8515

Chirag Vankani

TNO

Anca Anastasopol

TNO

\section{Earl Goetheer}

TNO

\section{Article}

Keywords: $\mathrm{CO} 2$ capture, carbon dioxide, electrochemical conversion, amine based capture solvents

Posted Date: September 3rd, 2020

DOI: https://doi.org/10.21203/rs.3.rs-62459/v1

License: (9) This work is licensed under a Creative Commons Attribution 4.0 International License. Read Full License

Version of Record: A version of this preprint was published at Industrial \& Engineering Chemistry Research on March 10th, 2021. See the published version at https://doi.org/10.1021/acs.iecr.0c05848. 


\title{
Integrating $\mathrm{CO}_{2}$ capture with electrochemical conversion using amine based capture solvents as electrolytes
}

\author{
Elena Pérez-Gallent*1 ${ }^{* 1}$ Chirag Vankani ${ }^{1}$, Anca Anastasopol ${ }^{1}$, Earl Goetheer*1,2 \\ ${ }^{1}$ Department of Sustainable Process and Energy Systems, TNO, Leeghwaterstraat 44, 2628 CA \\ Delft, The Netherlands \\ ${ }^{2}$ Process and Energy, Delft University of Technology, Leeghwaterstraat 39, 2628 CB Delft, The \\ Netherlands \\ *elena.perezgallent@tno.nl, $\underline{\text { *earl.goetheer@tno.nl }}$
}

\begin{abstract}
Carbon dioxide $\left(\mathrm{CO}_{2}\right)$ is currently considered as a waste material due to its negative impact on the environment. However, it is possible to create value from $\mathrm{CO}_{2}$ by capturing and utilizing it as a building block for commodity chemicals. Electrochemical conversion of $\mathrm{CO}_{2}$ has excellent potential for reducing greenhouse gas emissions and reaching the Paris agreement goal of zero net emissions by 2050. To date, Carbon Capture and Utilization (CCU) technologies (i.e. capture and conversion) have been studied independently. In this communication, we report a novel methodology based on the integration of $\mathrm{CO}_{2}$ capture and conversion by the direct utilization of a $\mathrm{CO}_{2}$ capture media as electrolyte for electrochemical conversion of $\mathrm{CO}_{2}$. This has a high potential for reducing capital and operational cost when compared to traditional methodologies (i.e. capture, desorption and then utilization). A novel mixture of chemical and physical absorption solvents allowed for the captured $\mathrm{CO}_{2}$ to be converted to formic acid with faradaic efficiencies up to $50 \%$ and with carbon conversion of ca. $30 \%$. By increasing the temperature in the electrochemical reactor from $20^{\circ} \mathrm{C}$ to $75^{\circ} \mathrm{C}$, the productivity towards formic acid increased by a factor of 10 , reaching up to $0.7 \mathrm{mmol} \cdot \mathrm{m}^{-2} \cdot \mathrm{s}^{-1}$. The direct conversion of captured $\mathrm{CO}_{2}$ was also demonstrated for carbon monoxide formation with faradaic efficiencies up $45 \%$.
\end{abstract}

\section{Introduction}

The abrupt increase of $\mathrm{CO}_{2}$ emissions into the atmosphere due to the use of fossil fuels creates adverse effects in the environment ${ }^{1,2}$. It is imperative that measures are implemented to drastically lower these emissions in pursuance of the Paris agreement. To date, many strategies have been contemplated with the ambition of achieving this purpose. Carbon capture and sequestration $(\mathrm{CCS})^{3-5}$, where $\mathrm{CO}_{2}$ is captured from industrial sources and stored underground, is and will remain, an important approach to diminishing atmospheric $\mathrm{CO}_{2}$ concentrations. Carbon capture can be considered a mature technology and has been used in a broad variety of industrial applications. Despite the high technology readiness of the technology, extensive studies are still being carried out to improve its economical feasibility and reduce the environmental footprint. For example, solvents which demand lower energy input, lead to less corrosion, and which undergo minimal thermal or oxidative degradation are being sought $\mathrm{t}^{6-8}$.

However, sequestration of captured carbon dioxide is still under debate due to its mid-term solution character, such as its limitation to areas where $\mathrm{CO}_{2}$ can be stored underground and its 
unprofitability ${ }^{9,10}$. An approach with a strategic long-term vision is $\mathrm{CO}_{2}$ capture and utilization (CCU), where the captured $\mathrm{CO}_{2}$ is used as a feedstock for the production of valuable chemicals. This approach creates value for $\mathrm{CO}_{2}$, leading to new value chains, and forming a stepping stone towards a circular carbon economy while realizing a sustainable way of reducing atmospheric $\mathrm{CO}_{2}$ concentration. To date, studies have approached $\mathrm{CO}_{2}$ capture $\mathrm{e}^{5,6,11-14}$ and conversion ${ }^{15-20}$ independently, whereas the strategy of this study was the integration of these two processes.

Electrochemical conversion of $\mathrm{CO}_{2}$ can be considered an efficient strategy for $\mathrm{CO}_{2}$ utilization due to the mild operating conditions and the possibility of tailor-made reaction pathways ${ }^{17}$. Preliminary techno-economic analysis has determined that the most economically viable products from $\mathrm{CO}_{2}$ are those where only 2 electron transfers are involved, such as carbon monoxide or formate ${ }^{21}$. Nevertheless, several hurdles need to be overcome in order to industrialize the electrochemical conversion of $\mathrm{CO}_{2}{ }^{22}$. One of the most significant challenges is related to the poor solubility of $\mathrm{CO}_{2}{ }^{23}$ in the electrolyte, leading to mass transfer limitations which limit current densities and reduce overall reaction efficiencies ${ }^{24,25}$.

Several strategies to increase the productivity of added-value chemicals from $\mathrm{CO}_{2}$ have been investigated, such as the use of gas diffusion electrodes $(G D E)^{26-28}$, the use of elevated pressures $^{29,30}$ and the use of non-aqueous electrolytes ${ }^{31,32}$ in order to increase the availability of the gas reactant at the electrochemical surface. However, from a complete system approach, the $\mathrm{CO}_{2}$ capture step is still required for the overall process. Therefore, this study proposed an integrated approach where $\mathrm{CO}_{2}$ capture and conversion are combined by using the capturing media as an electrolyte for the electrochemical conversion process.

The use of $\mathrm{CO}_{2}$ capture solvents as electrolytes can overcome the above-mentioned limitations of a conventional electrochemical system by allowing the absorbed $\mathrm{CO}_{2}$ to be feed into the electrolyzer at high concentration, thereby decreasing mass transfer limitations and increasing overall process efficiency ${ }^{33}$. Additionally, this integrated approach offers the benefit of removing the $\mathrm{CO}_{2}$ purification step - a desorption column - from in the conventional capture process. $\mathrm{CO}_{2}$ desorption is energy intensive and therefore expensive, so substituting this with a direct (electrochemical) conversion step leads to an improvement of the economic feasibility of the overall integrated process ${ }^{34,35}$. Jens et. al. assessed cost saving by integrating $\mathrm{CO}_{2}$ capture with utilization and concluded that with an upstream higher than $30 \mathrm{~mol} \% \mathrm{CO}_{2}, 46 \%$ savings in energy demand can be achieved when compared to a process without integration ${ }^{36}$.

Figure 1 shows a schematic representation of the two possible routes for CCU technologies: conventional decoupled $\mathrm{CO}_{2}$ capture and conversion, and integrated $\mathrm{CO}_{2}$ capture and conversion. 


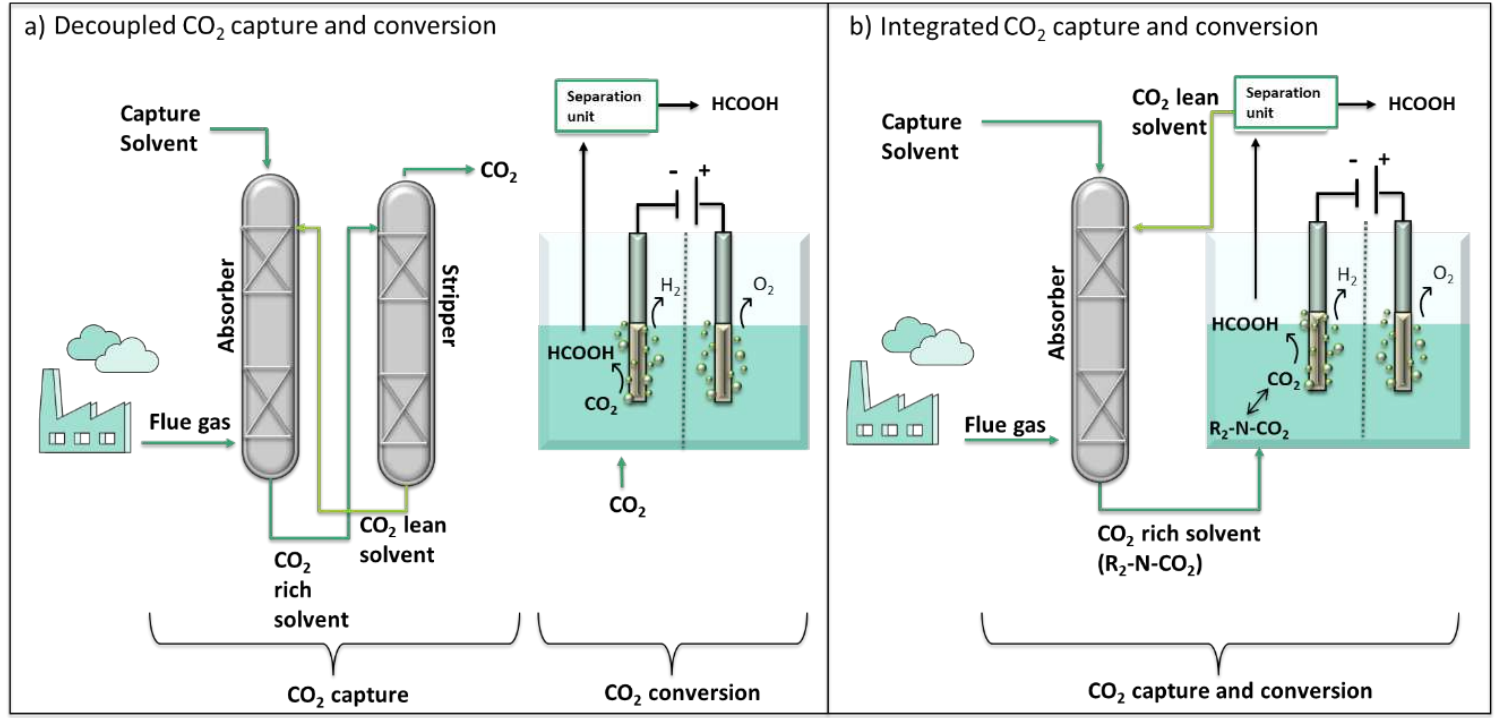

Figure 1. Schematic representation of the two possible routes for $\mathrm{CO}_{2}$ capture and utilization (CCU) technologies. a) Decoupled $\mathrm{CO}_{2}$ capture and conversion and b) Proposed integrated $\mathrm{CO}_{2}$ capture and conversion, where $\mathrm{R}_{2}-\mathrm{N}-\mathrm{CO}_{2}$ stands for absorbed $\mathrm{CO}_{2}$ in an amine solution as a carbamate/bicarbonate form.

In the frame of $\mathrm{CCU}$, the integration of $\mathrm{CO}_{2}$ capture with $\mathrm{CO}_{2}$ conversion must be addressed at the early development stage since a synergy between them is of paramount importance. Therefore, the selection of a capture medium should be appraised together with the compatibility assessment of that medium as electrolyte for electrochemical conversion. Finding suitable solutions for both capture and conversion processes will lead to a more robust system for the reduction of $\mathrm{CO}_{2}$ emissions.

A limited number of studies have addressed the use of $\mathrm{CO}_{2}$ capturing media for further electrochemical conversion. Chen et al. studied the electrochemical conversion of $\mathrm{CO}_{2}$ in a monoethanolamine (MEA) containing solution ${ }^{37}$. However, a constant feed of gaseous $\mathrm{CO}_{2}$ was required as reduction of the captured $\mathrm{CO}_{2}$ species was not observed. Diaz et al. reported, for the first time, the reduction of $\mathrm{CO}_{2}$ to $\mathrm{CO}$ in switchable polarity solvents which can also be used for $\mathrm{CO}_{2}$ capture ${ }^{38}$. However, this study showed low faradaic efficiencies towards $\mathrm{CO}$ (ca. $20 \%$ ), partially due to the aqueous nature of the solvent.

This study proposes a novel methodology that integrates $\mathrm{CO}_{2}$ capture and conversion using a mixture of chemical and physical $\mathrm{CO}_{2}$ absorption solvents as electrolytes. This presents the benefit of the abatement of continuous $\mathrm{CO}_{2}$ feeding as a source of free $\mathrm{CO}_{2}$. More specifically, it comprises the reduction of $\mathrm{CO}_{2}$ towards formic acid, glycolic acid, oxalic acid and carbon monoxide in a mixture of 2-amino-2-methyl-1-propanol (AMP) and propylene carbonate (PC) solution. The presented technology comprises the in situ liberation of the captured $\mathrm{CO}_{2}$ in the electrolyzer by increasing the temperature of the electrolyte in the vicinity of the electrode. This technology utilizes the inherent elevated temperature that is reached in electrolyzers at industrial scale due to the ohmic losses of the electrochemical system, thereby benefiting from what at first consideration might be perceived a drawback in the process. 


\section{Proposed system}

The proposed integrated $\mathrm{CO}_{2}$ capture and conversion system comprises of three main steps: absorption of $\mathrm{CO}_{2}$ in the chemical capture solvent, liberation of the absorbed $\mathrm{CO}_{2}$ inside the electrolyzer, and electrochemical conversion of the in-situ liberated $\mathrm{CO}_{2}$.

The most developed and extensively utilized capture solvents for $\mathrm{CO}_{2}$ are those based on thermally regenerable solvents such as MEA or AMP, among others ${ }^{39}$. In the capture step, $\mathrm{CO}_{2}$ reacts exothermically with non-hindered primary and secondary amines to form a carbamatespecies according to Eq 1 . In the presence of water, due to the steric hindrance of AMP, bicarbonate is formed according to Eq 2 .

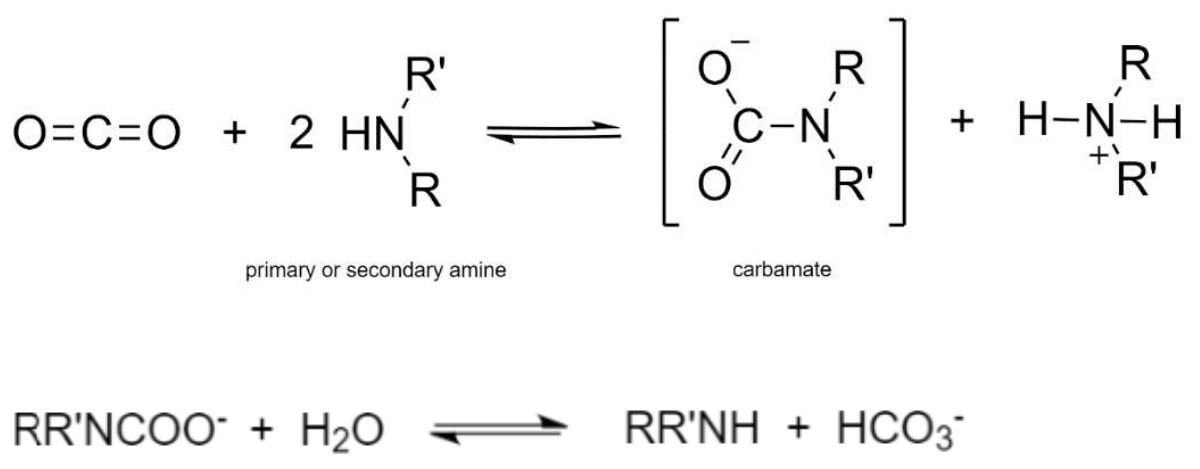

In the absence of water, for each mol of AMP used, $0.5 \mathrm{~mol}$ of carbamate is formed, resulting in a theoretical $\mathrm{CO}_{2}$ absorption of $22 \mathrm{~g} / \mathrm{L}$ when a $1 \mathrm{M}$ AMP solution is used ${ }^{40}$. This $\mathrm{CO}_{2}$ loading capacity is considerably higher than the absorption capacity of aqueous solutions at ambient conditions (ca. $1.5 \mathrm{gr} / \mathrm{L}$ ).

In a conventional $\mathrm{CO}_{2}$ capture unit, the enriched $\mathrm{CO}_{2}$ solution is introduced into a stripper where, by the addition of thermal energy, the complexation is reversed, leading to the liberation of $\mathrm{CO}_{2}$ and the generation of lean capture solvent. However, in the proposed technology, the solvent with the carbamate/bicarbonate species is feed into the cathodic side of an electrochemical reactor where the captured $\mathrm{CO}_{2}$ is desorbed in the vicinity of the electrode surface, as a result of the equilibrium reaction (eq 1 ). In order to promote the in situ liberation of $\mathrm{CO}_{2}$, the electrochemical reactor is maintained at an elevated temperature $\left(\sim 75^{\circ} \mathrm{C}\right)$. This mild temperature increase can easily be reached inside industrial size electrochemical reactors due to the associated ohmic losses of the electrochemical process which translate into heat.

The liberated $\mathrm{CO}_{2}$ is then electrochemically converted to formic acid, carbon monoxide or oxalic acid on the cathode according to Eq. 3-5, thereby shifting the equilibria in equation (1) back to the regeneration of the amine.

$$
\begin{aligned}
& \mathrm{CO}_{2}+2 \mathrm{H}^{+}+2 \mathrm{e}^{-} \rightarrow \mathrm{HCOOH} \\
& \mathrm{CO}_{2}+2 \mathrm{H}^{+}+2 \mathrm{e}^{-} \rightarrow \mathrm{CO}+\mathrm{H}_{2} \mathrm{O}
\end{aligned}
$$


The anodic reaction is based on water oxidation to oxygen according to Eq. 6.

$2 \mathrm{H}_{2} \mathrm{O} \rightarrow \mathrm{O}_{2}+4 \mathrm{H}^{+}+4 \mathrm{e}^{-}$

According to these equations, the presence of protons is essential for $\mathrm{CO}_{2}$ conversion. This can arise from two different sources. Firstly, in the trace amounts of water in the catholyte as a result of proton transfer through the cationic exchange membrane (CEM) that separates anolyte and catholyte compartments. The water content before and during electrolysis was measured with titration and it was found to increase with time due to diffusion through the membrane (See section 1 in the supporting information). Higher water content was measured in the catholyte when electrolysis experiments were carried out at $75{ }^{\circ} \mathrm{C}$ versus $20{ }^{\circ} \mathrm{C}$ (See Figure S. 1 in the Supporting Information). Secondly, the protonated amine counterion which is formed in situ with the carbamate species. This was proposed by Chen et.al. ${ }^{37}$ for $\mathrm{CO}_{2}$ reduction in MEA according to Eq. 7. However, it should be noted that if protons are abundant in solution, the competitive Hydrogen Evolution Reaction (HER) might be expected to dominate and the selectivity towards the desired products might be negatively affected.

$\mathrm{CO}^{-*}+[\mathrm{AMPH}]^{+}+\mathrm{e}^{-} \leftrightarrow\left[\mathrm{HCOO}^{-}+\mathrm{AMP}\right.$

Following reaction, the regenerated amine solution with residual unconverted $\mathrm{CO}_{2}$ exiting the electrolyzer can then be introduced in the absorber column to capture $\mathrm{CO}_{2}$, thereby recycling the capture solvent. It is important to note that in the proposed system where a liquid product is formed (e.g. formic acid) prior recycling of the capture solvent a separation and purification step is needed in order to remove the $\mathrm{CO}_{2}$ reduction product and traces of water from the solvent.

\section{$\underline{\text { Results and discussion }}$}

Cyclic voltammetry measurements were carried out to evaluate the viability of $\mathrm{CO}_{2}$ reduction in the capture media. Figure 2 shows the cyclic voltammograms performed on a $\mathrm{Pb}$ electrode in $\mathrm{PC}$ solution in the presence and absence of capture media (AMP), and in the presence of captured $\mathrm{CO}_{2}$, at different temperatures. 


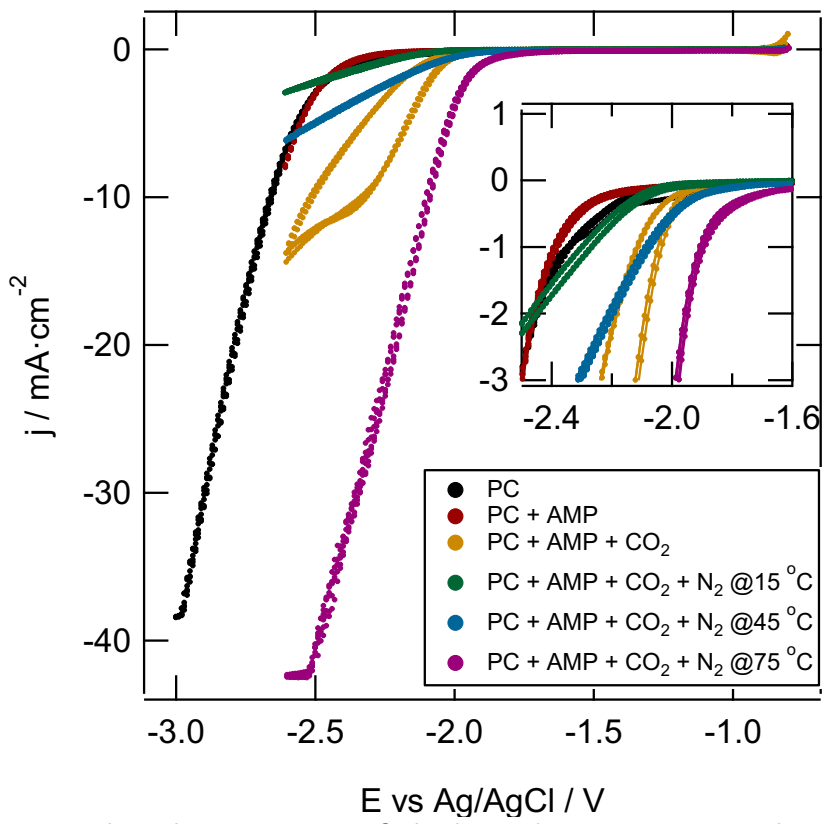

Figure 2. Cyclic voltammograms of Pb electrode in a $0.7 \mathrm{M} \mathrm{TEACl}$ in propylene carbonate solution in the absence of 2amino-2-methyl-1-propanol (AMP) (black line), in the presence of $1 \mathrm{MAMP}$ (red line), in the presence of $\mathrm{CO}_{2} \mathrm{Captured}^{\mathrm{C}}$ 1 bar and $15^{\circ} \mathrm{C}$ in $1 \mathrm{M} \mathrm{AMP}$ (yellow line), in the presence of $\mathrm{CO}_{2}$ captured in $1 \mathrm{M} \mathrm{AMP}$ after removal of free $\mathrm{CO}_{2}$ with $\mathrm{N}_{2}$ and at $15^{\circ} \mathrm{C}$ (green line), in the presence of $\mathrm{CO}_{2}$ captured in $1 \mathrm{M} \mathrm{AMP}$ after removal of free $\mathrm{CO} 2$ with $\mathrm{N}_{2}$ and at $45^{\circ} \mathrm{C}$ (blue line) and in the presence of $\mathrm{CO}_{2}$ captured in $1 \mathrm{M} \mathrm{AMP}$ after removal of free $\mathrm{CO}_{2}$ with $\mathrm{N}_{2}$ and at $75{ }^{\circ} \mathrm{C}$ (purple line). Inset displays a zoom in between $-1.6 \mathrm{~V}$ and $-2.5 \mathrm{~V}$ vs $\mathrm{Ag} / \mathrm{AgCl}$.

When $\mathrm{CO}_{2}$ is added to the electrolyte, a reduction current which was not present in the blank is observed with an onset potential of $-2 \mathrm{~V}$ vs $\mathrm{Ag} / \mathrm{AgCl}$. However, if the electrolyte is flushed with nitrogen gas to remove non-complexed $\mathrm{CO}_{2}$, the current density profile is very similar to that measured for the solution without $\mathrm{CO}_{2}$ (blank). This indicates reduction barely occurs, suggesting that the carbamate/bicarbonate species are not themselves directly reduced. Interestingly, when the temperature of the electrolyte is raised to $45^{\circ} \mathrm{C}$, a reduction current is observed with an onset potential of $-2 \mathrm{~V}$ vs $\mathrm{Ag} / \mathrm{AgCl}$. This result suggests that when the temperature is increased, the desorbed $\mathrm{CO}_{2}$ from the carbamate species undergoes electrochemical reduction. When the temperature of the electrolyte is increased to $75^{\circ} \mathrm{C}$, a considerably higher current is observed with an onset potential of $-1.8 \mathrm{~V}$ vs $\mathrm{Ag} / \mathrm{AgCl}$. The higher current observed at $75{ }^{\circ} \mathrm{C}$ compared to $45^{\circ} \mathrm{C}$ can be explained by increased $\mathrm{CO}_{2}$ desorption at the higher temperature. It is important to mention that the $\mathrm{CO}_{2}$ preloaded electrolyte forms a biphasic system at ambient temperatures, while at temperatures above $60^{\circ} \mathrm{C}$ the system is monophasic. The higher solubility of carbamates at higher temperature and the lower viscosity of the solution enhances the mass transfer.

In order to shed light onto the nature of the formed reduction products and to better comprehend the effect of the temperature during the electrochemical reduction of the captured $\mathrm{CO}_{2}$, chronoamperometric studies were carried out at a constant potential of $-2.5 \mathrm{~V} \mathrm{vs} \mathrm{Ag} / \mathrm{AgCl}$ on a $\mathrm{Pb}$ electrode at different temperatures (Figure 3).

In accordance with the cyclic voltammetry results, the current density measured during electrolysis substantially increased when the electrolyte temperature was increased, rising from $-3.9 \mathrm{~mA} / \mathrm{cm}^{2}$ at $15^{\circ} \mathrm{C}$ to $-25 \mathrm{~mA} / \mathrm{cm}^{2}$ at $75^{\circ} \mathrm{C}$. 
After 5 hours of electrolysis, three different products were detected in the liquid phase: formic, glycolic and oxalic acids. The productivity for these products was higher at higher electrolyte temperatures, being significantly higher for formic acid. The productivity to formic acid increased 10 times when the temperature was raised from $15{ }^{\circ} \mathrm{C}$ to $75{ }^{\circ} \mathrm{C}$ (reaching $0.56 \mathrm{mmol} / \mathrm{m}^{2} \cdot \mathrm{s}$ ).

Interestingly, the faradaic efficiency is relatively independent of the temperature. Moreover, it is important to note that high faradaic efficiencies towards formic acid (40\%) were observed at 75 ${ }^{\circ} \mathrm{C}$, while also showing high formic acid productivity $\left(0.56 \mathrm{mmol} / \mathrm{m}^{2} \cdot \mathrm{s}\right)$. For comparison, AlvarezGuerra et. al. showed a maximum productivity for formate on $\mathrm{Pb}$ electrodes in aqueous bicarbonate solution of ca. $0.35 \mathrm{mmol} / \mathrm{m}^{2}$ s with a Faradaic efficiency of ca. $30 \%{ }^{41}$. Although they also reported higher faradaic efficiencies for formate production (ca. $80 \%$ ), the productivity of formate at this high faradaic efficiency is only ca. $0.075 \mathrm{mmol} / \mathrm{m}^{2} \mathrm{~s}$, with a low current density of $2.5 \mathrm{~mA} / \mathrm{cm}^{2}$.

a)

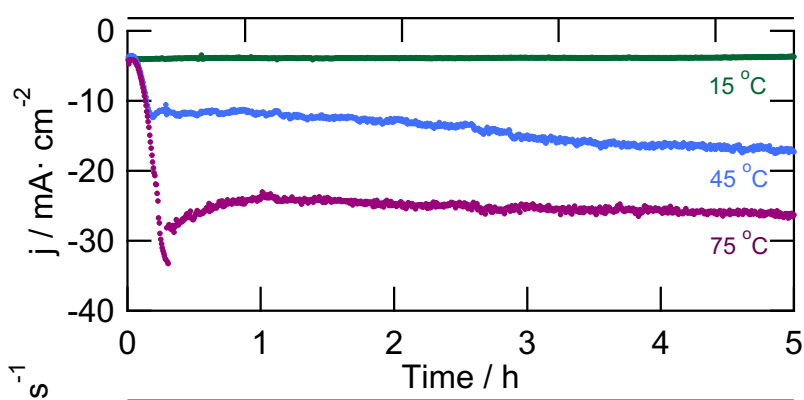

b)

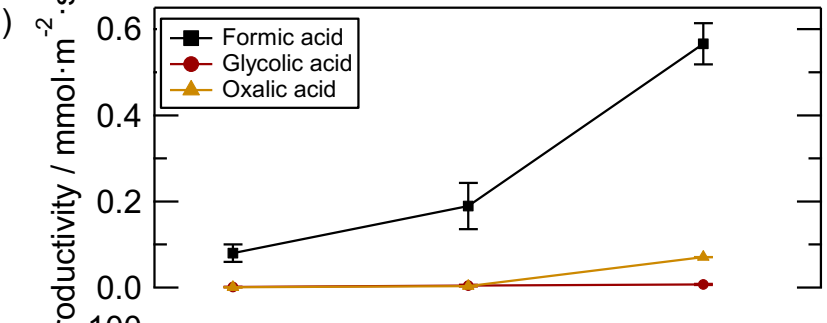

c)

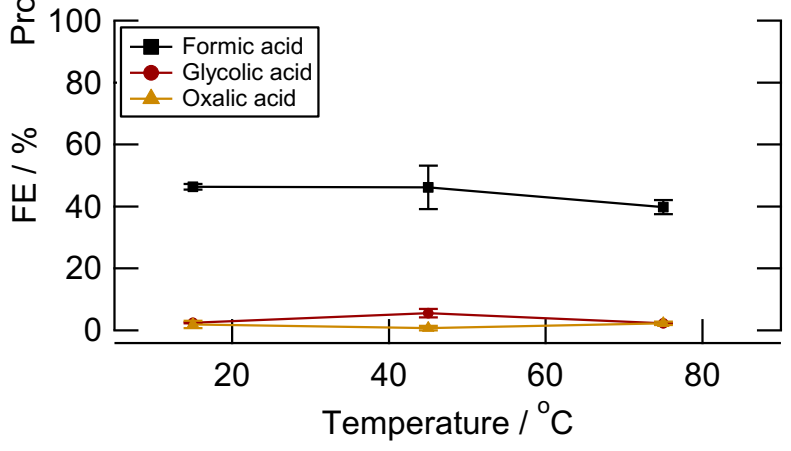

Figure 3. a) Chronoamperometry at $-2.5 \mathrm{~V}$ vs $\mathrm{Ag} / \mathrm{AgCl}$ on $\mathrm{Pb}$ electrode in a $0.7 \mathrm{M} \mathrm{TEACl}$ in PC solution containing $1 \mathrm{M}$ AMP preloaded with $\mathrm{CO}_{2}$ as a function of time at different temperatures $\left(15,45\right.$ and $\left.75^{\circ} \mathrm{C}\right)$. b) Productivity of formic acid, glycolic acid and oxalic acid as a function of the temperature during electrolysis at -2.5 V vs Ag/AgCl. c) Average faradaic efficiency during electrolysis at $-2.5 \mathrm{~V} v \mathrm{Ag} / \mathrm{AgCl}$ of formic acid, glycolic acid and oxalic acid as a function of the temperature.

In order to assess the importance of the organic solvent (propylene carbonate) as opposed to water, a control experiment was carried out on a 1M AMP aqueous solution (see Figure S.2 in Supporting Information). When electrolysis was performed at $-2.5 \mathrm{~V}$ vs $\mathrm{Ag} / \mathrm{AgCl}$ on a $\mathrm{Pb}$ electrode in a $\mathrm{CO}_{2}$ saturated $1 \mathrm{M}$ AMP aqueous solution at $75^{\circ} \mathrm{C}$, a high current density was measured (ca. - 
$40 \mathrm{~mA} / \mathrm{cm}^{2}$ ). However, low faradaic efficiencies towards formic acid were observed (ca. $13 \%$ after $1 \mathrm{~h}$ of electrolysis and ca. $3 \%$ after $5 \mathrm{~h}$ of electrolysis). The high current densities can be attributed to the competitive reduction reaction, namely HER, due to the increased temperatures promoting this reaction when water is present. As such, exchanging the organic solvent with water results in a significant negative effect on the selectivity of the reaction, reducing the efficiency of formic acid formation by ca. $70 \%$.

The $\mathrm{CO}_{2}$ concentration $(\alpha)$ in the solvent mixture was measured before and during electrolysis using the so-called $\mathrm{BaCO}_{3}$ precipitation method as described by Li et. al. ${ }^{42}$ and Santos et. al. ${ }^{43}$. Figure 4 shows the $\mathrm{CO}_{2}$ loading (moles of $\mathrm{CO}_{2}$ /moles $\mathrm{AMP}$ ) as a function of time at different electrolysis temperatures. The maximum $\mathrm{CO}_{2}$ loading achieved prior to reaction was ca. $0.35 \mathrm{~mol}$ $\mathrm{CO}_{2} / \mathrm{mol} A M P$, decreasing over time as a result of the desorption of $\mathrm{CO}_{2}$ during the equilibrium reaction (1). The $\mathrm{CO}_{2}$ loading decreases sharply in time as the temperature of the electrolyte is increased, indicating a faster $\mathrm{CO}_{2}$ desorption rate at higher temperatures. After $5 \mathrm{~h}$, the $\mathrm{CO}_{2}$ loading is ca. $10 \%$ of the initial value when electrolysis is performed at $75^{\circ} \mathrm{C}$ and ca. $93.5 \%$ of the initial value when performed at $15^{\circ} \mathrm{C}$.

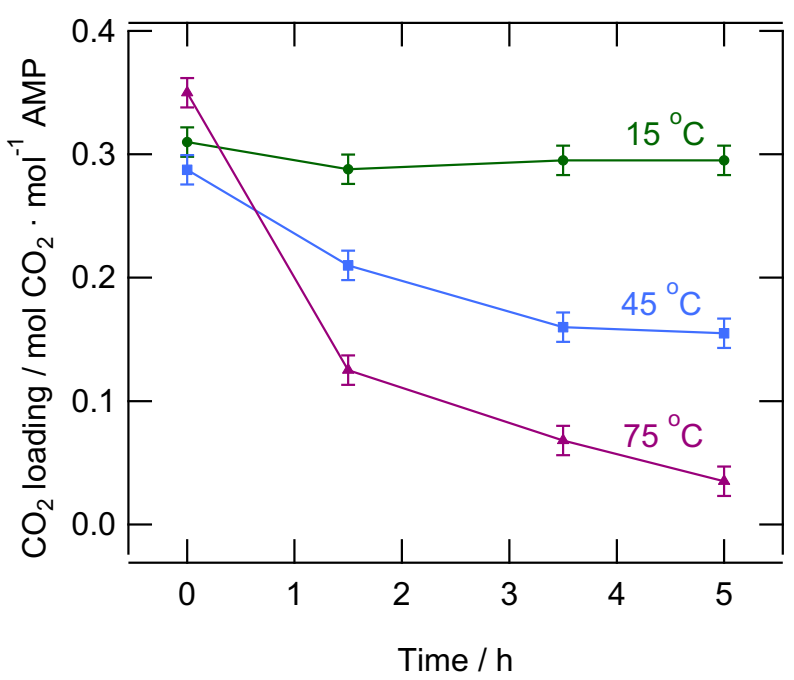

Figure 4. $\mathrm{CO}_{2}$ loading measured during electrolysis at $-2.5 \mathrm{~V}$ vs $\mathrm{Ag} / \mathrm{AgCl}$ on $\mathrm{Pb}$ electrode in a $0.7 \mathrm{MTEACl}$ in $\mathrm{PC}$ solution containing $1 \mathrm{M} A M P$ preloaded with $\mathrm{CO}_{2}$ as a function of time at different temperatures $\left(15,45\right.$ and $\left.75^{\circ} \mathrm{C}\right)$ as a function of time. $\mathrm{CO}_{2}$ loading refers to all the $\mathrm{CO}_{2}$ loading species including carbamates and bicarbonates.

The conversion of the liberated $\mathrm{CO}_{2}$ is shown in Figure $5 \mathrm{a}$ and it was calculated as:

$$
\mathrm{CO}_{2} \text { conversion } \%=\frac{n_{\mathrm{CO}_{2} \text { converted }}}{n_{\mathrm{CO}_{2} \text { liberated }}} \times 100
$$

Where $n_{\mathrm{CO}_{2}}$ converted was calculated as: 


$$
\mathrm{CO}_{2} \text { converted }=\sum_{j} v_{j}^{\mathrm{CO}_{2}} \cdot n_{P_{j}}
$$

Where $v_{j}^{\mathrm{CO}_{2}}$ is the $\mathrm{CO}_{2}$ stochiometric coefficient for the formation of formic acid $\left(\mathrm{j}_{1}\right)$, glycolic acid $\left(\mathrm{j}_{2}\right)$ and oxalic acid $\left(\mathrm{j}_{3}\right)$ from $\mathrm{CO}_{2}$ and $\mathrm{n}_{\mathrm{Pj}}$ is the formed moles of products.

$n_{\mathrm{CO}_{2}}$ liberated was calculated as:

$$
\mathrm{CO}_{2} \text { liberated }=n_{\text {initial }}^{\mathrm{CO}_{2}}-n_{\text {final }}^{\mathrm{CO}_{2}}
$$

Where $n_{\text {initial }}^{\mathrm{CO}_{2}}$ is the moles of $\mathrm{CO}_{2}$ captured in $1 \mathrm{M} \mathrm{AMP}$ in PC solution before electrolysis and $n_{\text {final }}^{\mathrm{CO}_{2}}$ is the moles of residual captured $\mathrm{CO}_{2}$ after a given electrolysis time.

The amount of $\mathrm{CO}_{2}$ liberated (Figure $5 \mathrm{~b}$ ) at $75^{\circ} \mathrm{C}$ after $5 \mathrm{~h}$ is approximately 7 times higher than at $15^{\circ} \mathrm{C}$. Correspondingly, the amount of $\mathrm{CO}_{2}$ converted after $5 \mathrm{~h}$ of electrolysis at $75^{\circ} \mathrm{C}$ is 8 times higher than at $15^{\circ} \mathrm{C}$ (Figure $5 \mathrm{c}$ ). Importantly, the highest conversion after 5 hours of electrolysis (ca. $30 \%$ ) was achieved when the electrolyte was kept at $45{ }^{\circ} \mathrm{C}$ (Figure $5 \mathrm{a}$ ) due to there being a better balance between the amount of $\mathrm{CO}_{2}$ liberated and that being converted. It is important to note that the electrolysis was carried out in an open system, therefore, all the desorbed $\mathrm{CO}_{2}$ that didn't react was vented out of the system. Thereby, closing the system and operating it at elevated pressures, would allow non-converted $\mathrm{CO}_{2}$ to be absorbed again increasing the conversion.

The increase of temperature required to desorb the $\mathrm{CO}_{2}$ from the capture solvent might at first seem an extra operational cost for the system, however, when electrolysis is carried out at higher current densities and/or in a stack reactor, the inherent ohmic losses ${ }^{44}$ associated with the electrochemical reaction are converted into heat. These are usually seen as a disadvantage, however, with the current integrated $\mathrm{CO}_{2}$ capture and conversion strategy, they can now be advantageously utilized to improve the electrolysis process. 
a)

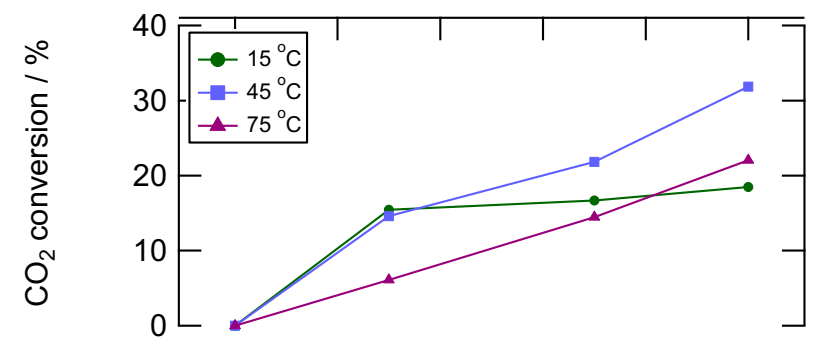

b)

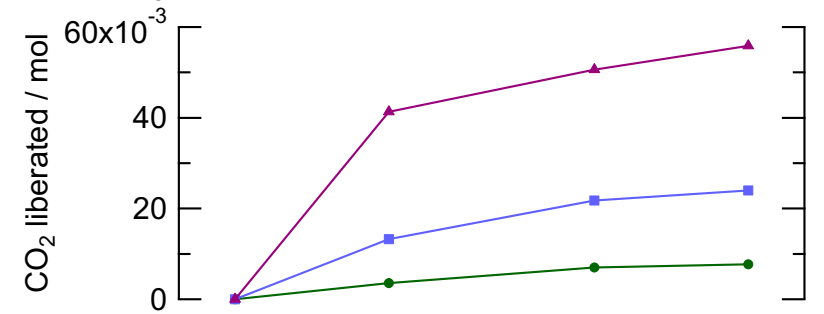

c)

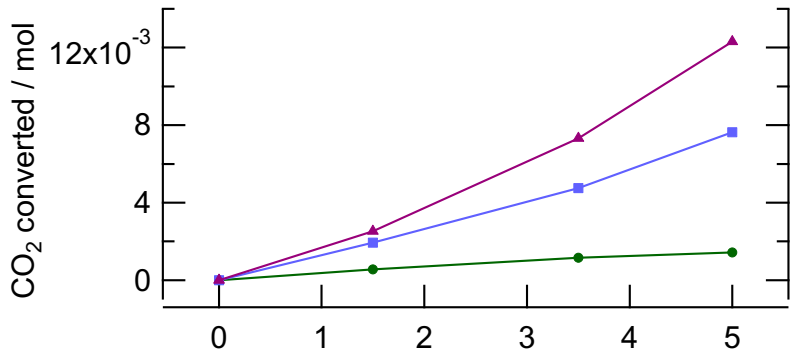

time / $\mathrm{h}$

Figure 5. a) $\mathrm{CO}_{2}$ conversion on a Pb electrode in a $1 \mathrm{M} A M P$ in $\mathrm{PC}$ solution as a function of time and temperature, b) $\mathrm{Moles}_{\text {of }} \mathrm{CO}_{2}$ liberated from a $1 M$ AMP in PC solution as a function of time and temperature, c) Moles of $\mathrm{CO}_{2}$ converted on a $\mathrm{Pb}$ electrode in a $1 M A M P$ in $P C$ solution as a function of time and temperature.

\section{Effect of the capture solvent concentration}

The concentration of the capture solvent (AMP) was varied between $0 \mathrm{M}$ and $3 \mathrm{M}$ in order to understand its influence on the electrolyte solution during $\mathrm{CO}_{2}$ reduction. Figure 6 shows the current density, productivity and faradaic efficiency towards formic acid, glycolic acid and oxalic acid, obtained on a $\mathrm{Pb}$ electrode during electrolysis at $-2.5 \mathrm{~V}$ vs $\mathrm{Ag} / \mathrm{AgCl}$ at $75^{\circ} \mathrm{C}$, as a function of the concentration of $\mathrm{AMP}$ in $\mathrm{PC}$, in a $\mathrm{CO}_{2}$ pre-saturated solution of the two. The current density increased from -10 to $-25 \mathrm{~mA} / \mathrm{cm}^{2}$ when the concentration of AMP was increased from $0 \mathrm{M}$ to $1 \mathrm{M}$, reaching a plateau between 1 and $2 \mathrm{M} \mathrm{AMP \text {, }}$ and decreasing to $-20 \mathrm{~mA} / \mathrm{cm}^{2}$ in $3 \mathrm{M}$ AMP. The maximum faradaic efficiency (ca. $50 \%$ ) and productivity (ca. $0.7 \mathrm{mmol} \mathrm{m}^{-2} \mathrm{~s}^{-1}$ ) of formic acid was observed when a concentration of $2 \mathrm{M} \mathrm{AMP} \mathrm{in} \mathrm{PC}$ was used. Interestingly, increasing capture solvent concentration also leads to a decrease in current densities, faradaic efficiency and productivity of formic acid. This lower efficiency may be explained due to the higher viscosity of the 3M AMP solution, giving rise to mass transfer limitations, as well as the lower conductivity of the solution, potentially leading to current limitations (See Table 1 in the Supporting Information). The higher viscosity might be explained due to the higher levels of carbamate due to the higher loading capacity of the solution and the low solubility of the carbamate species in PC.

Importantly, the faradaic efficiency and the productivity of oxalic acid is drastically increased when low levels/no AMP are present in the electrolyte solution. The highest faradaic efficiency towards oxalic acid 
was $80 \%$, measured after 1 hour of electrolysis in the absence of AMP. However, the faradaic efficiency towards oxalic acid decreased over time reaching ca. $20 \%$ after 5 hours of electrolysis due to the decrease in available $\mathrm{CO}_{2}$ (see Figure S.3 in the Supporting Information). While the results shown in Figure 6 are an average of five hours of electrolysis, faradaic efficiencies varied with time. Detailed information about their evolution over time as a function of the concentration of AMP and water content can be found in section 3 of the Supporting Information.

In general terms, it is clear that the nature of the electrolyte solution and the presence or absence of capture solvent significantly influences the product distribution.

a)

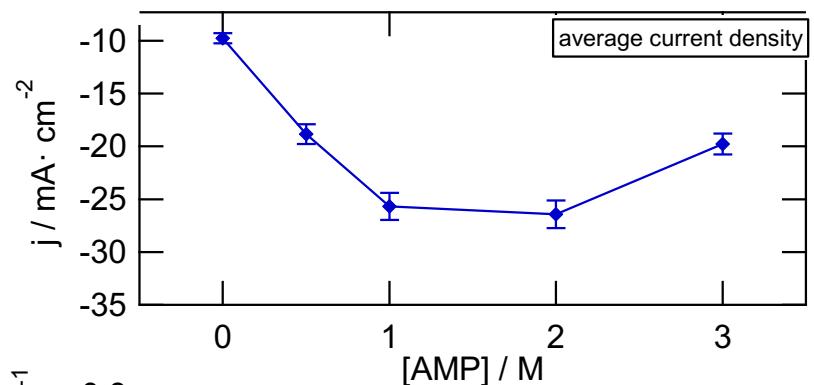

b)

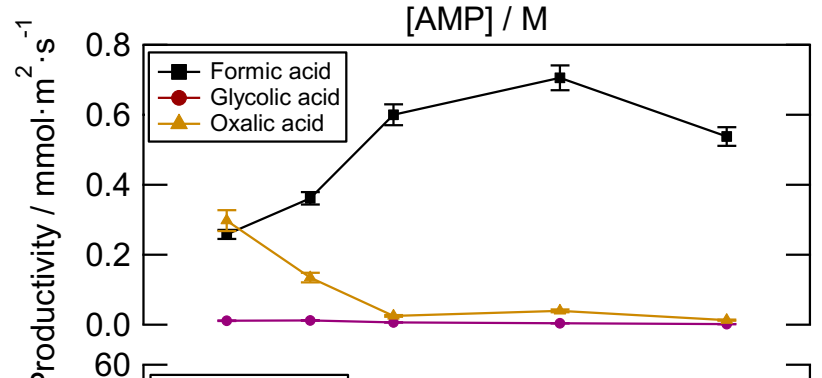

c)

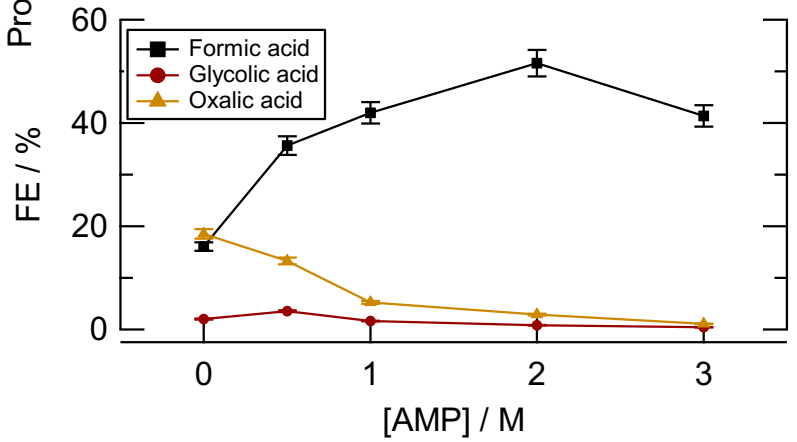

Figure 6. a) Average current density measured over 5 hours of electrolysis at $-2.5 \mathrm{Vvs} \mathrm{Ag/AgCl}$ at $75{ }^{\circ} \mathrm{C}$ on $\mathrm{Pb}$ electrode in a $\mathrm{CO}_{2}$ preloaded $0.7 \mathrm{M} \mathrm{TEACl}$ in $P C$ solution containing different concentrations of $A M P(0,0.5,1,2$ and $3 \mathrm{M})$. b) Productivity of formic acid, glycolic acid and oxalic acid as a function of the concentration of AMP during electrolysis at $-2.5 \mathrm{~V}$ vs $\mathrm{Ag} / \mathrm{AgCl}$ at $75^{\circ} \mathrm{C}$. c) Average faradaic efficiency during electrolysis at $-2.5 \mathrm{~V} \mathrm{vs}$. $\mathrm{Ag} / \mathrm{AgCl}$ at $75{ }^{\circ} \mathrm{C}$ of formic acid, glycolic acid and oxalic acid as a function of the concentration of AMP.

\section{Formic acid and CO formation in a continuous flow cell}

In order to make the first steps towards validating the proposed integrated $\mathrm{CO}_{2}$ carbon and conversion methodology for larger-scale production, on route to commercial implementation, the technology was transferred from batch to a scalable, (semi-)continuous reactor concept. Electrochemical reduction of a $\mathrm{CO}_{2}$ saturated $1 \mathrm{M}$ AMP in PC solution was carried out using an electrochemical flow cell in which the 
electrolyte was continuously circulated through the reactor (See Figure 7a). In order to promote desorption of $\mathrm{CO}_{2}$ in the vicinity of the electrode, a heating chamber was placed on the back of the metallic electrode, maintaining an electrode temperature of $75{ }^{\circ} \mathrm{C}$ during reaction. The results of these experiments (See Figure $7 \mathrm{~b}$ and $\mathrm{c}$ ), using a Pb electrode, are similar results to those obtained in batch mode (see Figure 6). Only a slight increase in current density and a slight decrease in faradaic efficiency towards formic acid were observed. More details can be found in Section 4 in the Supporting information.

Additionally, a different cathode material ( $\mathrm{Au}$ ) was investigated for $\mathrm{CO}_{2}$ reduction in the (semi-)continuous reactor concept, with the goal of extending the methodology to include the production of alternative products. It is known that in aqueous solutions, Au selectively reduces $\mathrm{CO}_{2}$ to $\mathrm{CO}^{45}$. During electrochemical reduction in a $1 \mathrm{M} A M P$ in $\mathrm{PC}$ solution preloaded with $\mathrm{CO}_{2}$ using a $\mathrm{Au}$ cathode, carbon monoxide was observed as the main product. Figure $7 \mathrm{~d}$ and e show the current density and the faradaic efficiency towards $\mathrm{CO}$ during electrolysis at different potentials. The highest faradaic efficiency towards $\mathrm{CO}$ (ca. $45 \%$ ) was obtained when the electrolysis was carried out at $-1.6 \mathrm{~V}$ vs $\mathrm{Ag} / \mathrm{AgCl}$ with a current density of ca. -15 $\mathrm{mA} / \mathrm{cm}^{2}$.

Further research to optimize the system, including the electrolyte composition and process conditions, is currently being carried out in our laboratories. Nevertheless, these results indicate the viability of implementing the proposed integrated $\mathrm{CO}_{2}$ capture and conversion system in a continuous process and shows its potential for the reduction of captured $\mathrm{CO}_{2}$ towards added-value chemicals such as formic acid or $\mathrm{CO}$. 
a)

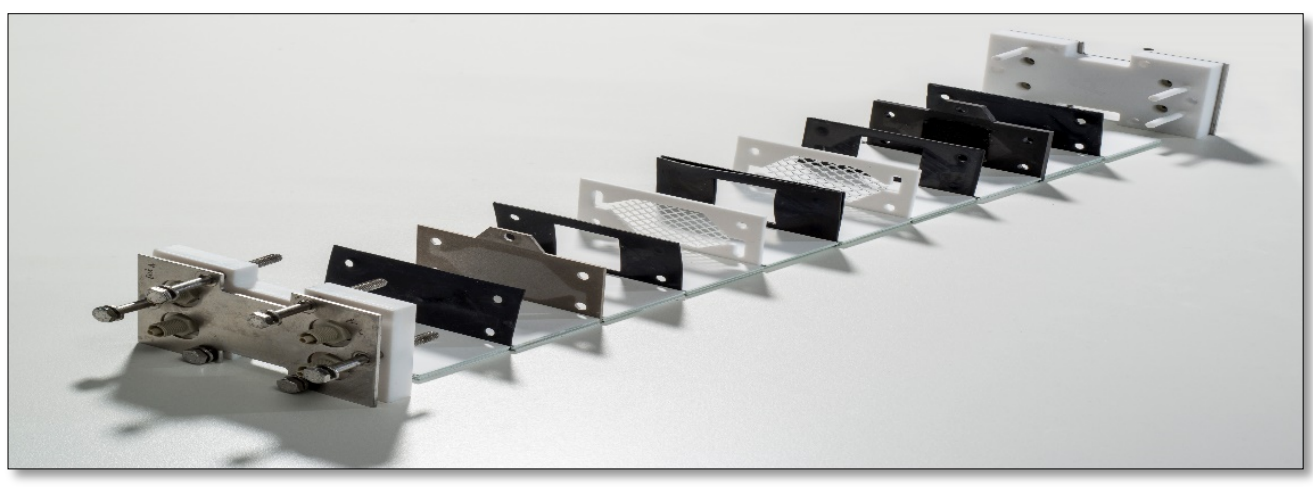

b)

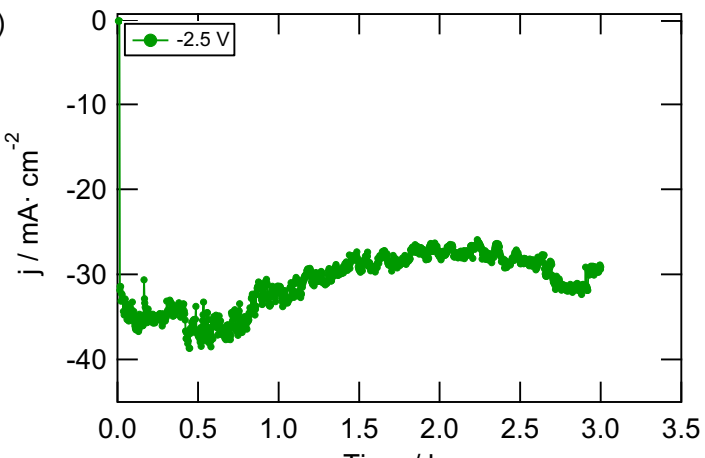

c)

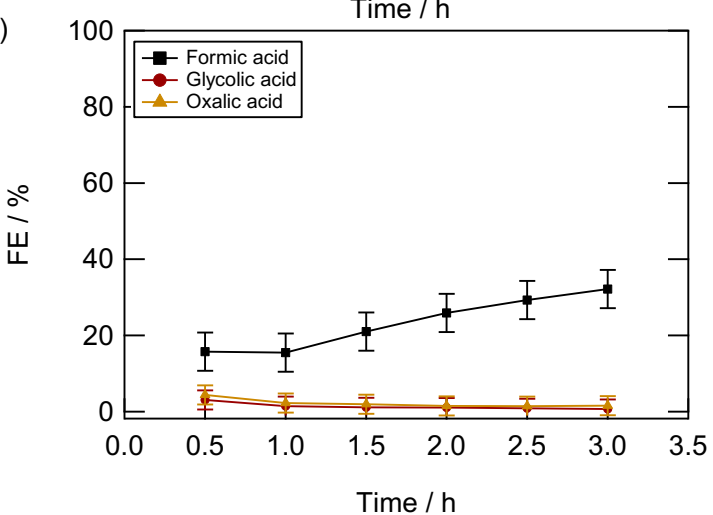

d)

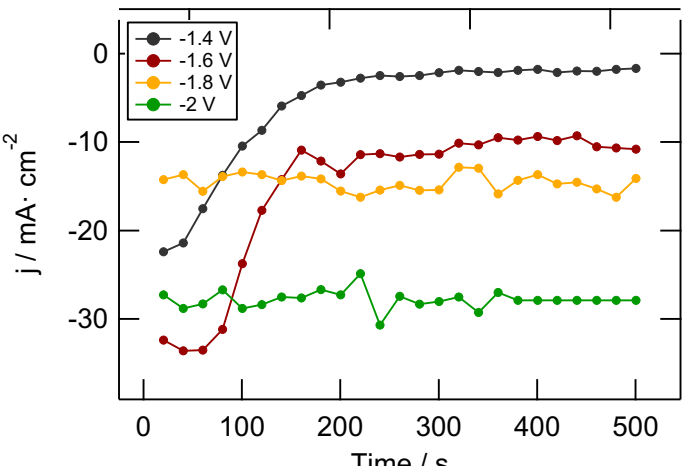

e)

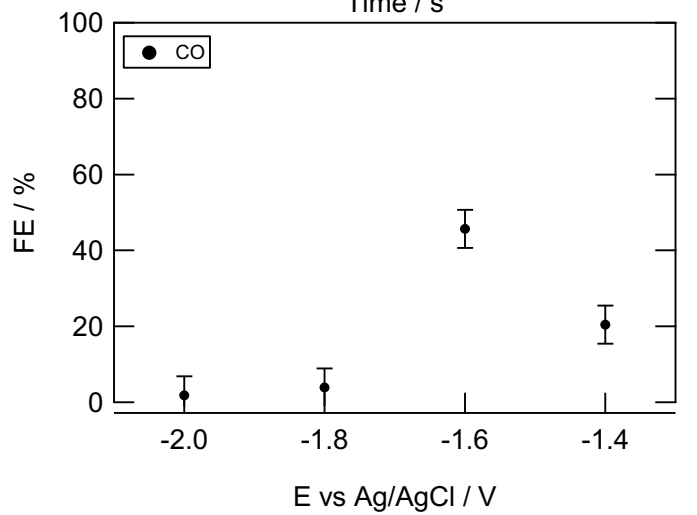

Figure 7. a) Electrochemical flow cell employed for $\mathrm{CO}_{2}$ conversion electrolysis on $\mathrm{Pb}$ electrodes ( $b$ and $c$ ) and on $\mathrm{Au}$ electrodes (d and e). b) current density and c) Faradaic efficiency towards formic acid, glycolic acid and oxalic acid measured during electrolysis at $75{ }^{\circ} \mathrm{C}$ on $\mathrm{Pb}$ electrode at $-2.5 \mathrm{~V} \mathrm{vs} \mathrm{Ag} / \mathrm{AgCl}$ in a $1 \mathrm{M} A M P$ in $P C$, preloaded with $\mathrm{CO}_{2}$. d) current density and e) Faradaic efficiency towards $\mathrm{CO}$ measured during electrolysis on Au electrode at -1.4, -1.6, 1.8 and $-2 \mathrm{~V}$ vs $\mathrm{Ag} / \mathrm{AgCl}$ in a $1 \mathrm{M}$ AMP in $\mathrm{PC}$, preloaded with $\mathrm{CO}_{2}$. 


\section{Conclusions}

This study demonstrates the feasibility of an integrated $\mathrm{CO}_{2}$ capture and conversion system, where a mixture of chemical and physical absorption solvents used for $\mathrm{CO}_{2}$ capture can be used as electrolyte in an electrochemical reactor to efficiently convert $\mathrm{CO}_{2}$ into formic acid and $\mathrm{CO}$.

This novel methodology is based on the liberation of the captured $\mathrm{CO}_{2}$ inside the electrochemical reactor by increasing the temperature of the system. An increase of temperature is an inherent trait of an electrochemical system, since the ohmic losses associated to the process lead to an increase of temperature. When a mixture of $1 \mathrm{M}$ AMP in $\mathrm{PC}$ was used as $\mathrm{CO}_{2}$ capture media and afterwards as electrolyte, $\mathrm{CO}_{2}$ conversion towards formic acid was achieved with faradaic efficiencies of ca. $45 \%$ and productivity of $0.56 \mathrm{mmol} / \mathrm{m}^{2} \cdot \mathrm{s}$ when the process was carried out at $75{ }^{\circ} \mathrm{C}$. The productivity of the integrated process significantly improved when increasing the temperature from $15{ }^{\circ} \mathrm{C}$ to $75{ }^{\circ} \mathrm{C}$. This increase in productivity is associated to the preponderant liberation of $\mathrm{CO}_{2}$ at elevated temperatures being 8 times higher at $75^{\circ} \mathrm{C}$ than at $15^{\circ} \mathrm{C}$.

The selection of an adequate electrolyte composition is essential for the selective formation of the desired product. For instance: substituting the physical solvent (PC) for water lead to a $70 \%$ decrease of formic acid production due to the higher production of hydrogen in aqueous media, while electrolysis in the absence of the capturing media (AMP) lead primarily to oxalic acid formation instead of formic acid. Importantly, doubling the concentration of the capture solvent to $2 \mathrm{M}$ showed an improvement on the efficiency reaching $50 \%$ and an improvement of the productivity of formic acid which reached 0.7 $\mathrm{mmol} / \mathrm{m}^{2} \cdot \mathrm{s}$. However, higher concentrations of AMP led to a decrease in the formic acid productivity and efficiency, possibly due to mass transfer limitations attributable to higher electrolyte viscosity. Thereby, the nature of the electrolyte and its relative composition play a significant role in the product distribution of the $\mathrm{CO}_{2}$ reduction reaction.

The proposed methodology was brought one step forward into the scaling-up process and the validation of the electrochemical conversion in a semi-continuous system using an flow reactor was achieved for formic acid and for $\mathrm{CO}$. The highest Faradaic efficiency towards $\mathrm{CO}$ (ca. $45 \%$ ) was achieved at $-1.6 \mathrm{~V}$ vs $\mathrm{Ag} / \mathrm{AgCl}$ with a current density of ca. $10 \mathrm{~mA} / \mathrm{cm}^{2}$.

This study presents a positive perspective in the implementation of the CCU technology by integrating $\mathrm{CO}_{2}$ capture and conversion processes towards added value chemicals, such as formic acid or carbon monoxide.

\section{Experimental}

A three-electrode electrochemical $\mathrm{H}$-cell and modular microflow cell (ElectroCell) were used to perform the electrochemical conversion of $\mathrm{CO}_{2}$ for batch and flow experiments, respectively. The $\mathrm{H}$-cell consisted of two compartments, while the flow cell had one extra compartment behind the cathode plate for heating purposes.

When working in the $\mathrm{H}$-cell, the working electrode was a Pb coil $\left(10 \mathrm{~cm}^{2}\right.$, Alfa Aesar, $\left.99.9 \%\right)$ and the counter electrode was Pt coil (30 $\mathrm{cm}^{2}$, Alfa Aesar, 99.9\%). When working in the continuous flow cell, the working electrode was $\mathrm{Pb}$ foil $\left(10 \mathrm{~cm}^{2}\right.$, Alfa Aesar, $\left.99.9 \%\right)$ for formic acid production and Au foil $\left(10 \mathrm{~cm}^{2}\right.$, Alfa Aesar, 99.9\%) for CO formation. The counter electrode was a platinized Titanium plate $\left(10 \mathrm{~cm}^{2}\right.$, ElectroCell). The reference electrode used in both cells was a leak-free $\mathrm{Ag} / \mathrm{AgCl}$ electrode (Innovative 
Instruments LF-1-100). The anode and cathode compartments in both cells were separated by pre-treated cation exchange membrane (Nafion-117). Prior to every experiment, the working and counter electrode were treated. $\mathrm{Pb}$ was treated electrochemically in a $0.5 \mathrm{M}$ aqueous $\mathrm{H}_{2} \mathrm{SO}_{4}$ by applying $-1.8 \mathrm{~V}$ vs $\mathrm{Pt}$ as counter electrode for $500 \mathrm{~s}$. The Pt coil was flame annealed, followed by quenching in Mili-Q water. Au foil was mechanically polished with alumina slurry, followed by sonication to remove trace alumina particles. All the glassware and cell components were rinsed with acetone and dried before using.

The anolyte consisted of a $0.5 \mathrm{M}$ aqueous $\mathrm{H}_{2} \mathrm{SO}_{4}$ solution and the catholyte consisted of different concentrations $(0,0.5,1,2$ and $3 \mathrm{M})$ of $\mathrm{AMP}$ and $0.7 \mathrm{M}$ tetraethylammonium chloride (TEAC) in PC. A stock solution of $3 \mathrm{M} \mathrm{AMP}$ and $0.7 \mathrm{M}$ TEAC in PC loaded with $\mathrm{CO}_{2}$ was prepared in bulk and later diluted to the desired concentration. The stock solution was loaded with $\mathrm{CO}_{2}$ at $15^{\circ} \mathrm{C}$ for 2 hours with a $\mathrm{CO}_{2}$ flow rate of $210 \mathrm{ml} / \mathrm{min}$, and was stored at $5{ }^{\circ} \mathrm{C}$. Prior to every $\mathrm{H}$-cell electrolysis experiment, 40 min of $\mathrm{N}_{2}$ purging at $15^{\circ} \mathrm{C}$ was performed to remove all non-complexed, dissolved $\mathrm{CO}_{2}$ from the catholyte solution. No extra $\mathrm{CO}_{2}$ was fed during electrolysis. The heating of the electrolyte to the desired temperature was started at the same time as the chronoamperometry. In continuous-flow experiments, the vessel containing the $\mathrm{CO}_{2}$ loaded catholyte was heated to $60{ }^{\circ} \mathrm{C}$ before starting chronoamperometry, to achieve a monophasic system, and avoid blockages in the recirculation pump. The measurements were carried in potentiostatic mode, applying a constant cathode potential of $-2.5 \mathrm{~V}$ for experiments carried out on $\mathrm{Pb}$ electrodes and different potentials ( $-1.4,-1.6,-1.8$ and $-2 \mathrm{~V}$ vs $\mathrm{Ag} / \mathrm{AgCl}$ ) for experiments on Au electrodes. The potentials were controlled by an Autolab potentiostat (PGSTAT20).

The liquid products obtained during the reduction of $\mathrm{CO}_{2}$ were collected every 30 minutes and analyzed using an Agilent High Performance Liquid Chromatograph (HPLC) system (1260-Infinity with and Amminex HPX-87H column and RID detector).

The gaseous products were analyzed using an Interscience gas chromatography (GC) system (Trace GC with a Supelco carboxen 1010 PLOT column and FID detector). $\mathrm{CO}_{2}$ loading of the catholyte solution was measured prior to and during operation by the barium carbonate $\left(\mathrm{BaCO}_{3}\right)$ precipitation method as described by Li et. al. ${ }^{42}$ and Santos et. al. ${ }^{43} .1 \mathrm{ml}$ of unfiltered catholyte solution was diluted with $10 \mathrm{ml}$ of Milli-Q water to dissolve any solids, then $10 \mathrm{ml}$ of $1 \mathrm{M} \mathrm{BaCl}_{2}$ was added to form $\mathrm{BaCO}_{3}$, which precipitates. This slurry was then titrated with $0.1 \mathrm{M} \mathrm{HCl}$ until the white precipitate disappeared completely.

\section{Acknowledgements}

The authors acknowledge VoltaChem for the financial support.

\section{Competing interests}

The authors declare no competing financial interest.

\section{Data availability}

The data that support the plots within this paper and other findings of this study are available from the corresponding author on reasonable request.

\section{References}

1 Yamasaki, A. An Overview of $\mathrm{CO}<\mathrm{SUB}>2</ \mathrm{SUB}>$ Mitigation Options for Global Warming\&mdash;Emphasizing $\mathrm{CO}<\mathrm{SUB}>2</ \mathrm{SUB}>$ Sequestration Options. JOURNAL OF CHEMICAL ENGINEERING OF JAPAN 36, 361-375, doi:10.1252/jcej.36.361 (2003).

2 Ayers, W. M. in Carbon Dioxide Chemistry (eds Jan Paul \& Claire-Marie Pradier) 365-374 (Woodhead Publishing, 1994).

3 Bennaceur, K. in Future Energy (Second Edition) (ed Trevor M. Letcher) 583-611 (Elsevier, 2014). 
Markewitz, P. et al. Worldwide innovations in the development of carbon capture technologies and the utilization of CO2. Energy \& Environmental Science 5, 7281-7305, doi:10.1039/C2EE03403D (2012).

5 Wilson, E. \& Gerard, D. Carbon capture and sequestration: integrating technology, monitoring, regulation. (Blackwell Publishing, Ames, IA (United States), 2007).

6 Meisen, A. \& Shuai, X. Research and development issues in $\mathrm{CO} 2$ capture. Energy Conversion and Management 38, S37-S42, doi:https://doi.org/10.1016/S0196-8904(96)00242-7 (1997).

7 Han, K. et al. Current status and challenges of the ammonia-based CO2 capture technologies toward commercialization. International Journal of Greenhouse Gas Control 14, 270-281, doi:https://doi.org/10.1016/j.ijggc.2013.01.007 (2013).

8 Jordal, K., Anheden, M., Yan, J. \& Strömberg, L. in Greenhouse Gas Control Technologies 7 (eds E. S. Rubin et al.) 201-209 (Elsevier Science Ltd, 2005).

9 Cuéllar-Franca, R. M. \& Azapagic, A. Carbon capture, storage and utilisation technologies: A critical analysis and comparison of their life cycle environmental impacts. Journal of CO2 Utilization 9, 82102, doi:https://doi.org/10.1016/j.jcou.2014.12.001 (2015).

10 Read, A. et al. Lessons from the ROAD project for future deployment of CCS. International Journal of Greenhouse Gas Control 91, 102834, doi:https://doi.org/10.1016/j.ijggc.2019.102834 (2019).

11 Thomas, D. \& Benson, S. Carbon Dioxide Capture for Storage in Deep Geologic Formations Results from the CO2 Capture Project : Vol 1 - Capture and Separation of Carbon Dioxide from Combustion, Vol 2 - Geologic Storage of Carbon Dioxide with Monitoring and Verification. (2005).

12 Yu, C.-H., Huang, C.-H. \& Tan, C.-S. A Review of CO2 Capture by Absorption and Adsorption. Aerosol and Air Quality Research 12, 745-769, doi:10.4209/aaqr.2012.05.0132 (2012).

13 Darde, V., Thomsen, K., van Well, W. J. M. \& Stenby, E. H. Chilled ammonia process for CO2 capture. Energy Procedia 1, 1035-1042, doi:https://doi.org/10.1016/j.egypro.2009.01.137 (2009).

14 Sanchez Fernandez, E. et al. Thermodynamic assessment of amine based CO2 capture technologies in power plants based on European Benchmarking Task Force methodology. Fuel 129, 318-329, doi:https://doi.org/10.1016/j.fuel.2014.03.042 (2014).

15 Huang, C.-H. \& Tan, C.-S. A Review: CO2 Utilization. Aerosol and Air Quality Research 14, 480-499, doi:10.4209/aaqr.2013.10.0326 (2014).

16 Zangeneh, F. T., Sahebdelfar, S. \& Ravanchi, M. T. Conversion of carbon dioxide to valuable petrochemicals: An approach to clean development mechanism. Journal of Natural Gas Chemistry 20, 219-231, doi:https://doi.org/10.1016/S1003-9953(10)60191-0 (2011).

17 Spinner, N. S., Vega, J. A. \& Mustain, W. E. Recent progress in the electrochemical conversion and utilization of CO2. Catalysis Science \& Technology 2, 19-28, doi:10.1039/C1CY00314C (2012).

18 Chen, Y., Li, C. W. \& Kanan, M. W. Aqueous CO2 Reduction at Very Low Overpotential on OxideDerived Au Nanoparticles. Journal of the American Chemical Society 134, 19969-19972, doi:10.1021/ja309317u (2012).

19 Morales-Guio, C. G. et al. Improved $\mathrm{CO} 2$ reduction activity towards $\mathrm{C} 2+$ alcohols on a tandem gold on copper electrocatalyst. Nature Catalysis 1, 764-771, doi:10.1038/s41929-018-0139-9 (2018).

20 Birdja, Y. Y. et al. Advances and challenges in understanding the electrocatalytic conversion of carbon dioxide to fuels. Nature Energy 4, 732-745, doi:10.1038/s41560-019-0450-y (2019).

21 Verma, S., Kim, B., Jhong, H.-R. M., Ma, S. \& Kenis, P. J. A. A Gross-Margin Model for Defining Technoeconomic Benchmarks in the Electroreduction of CO2. ChemSusChem 9, 1972-1979, doi:10.1002/cssc.201600394 (2016).

22 Bushuyev, O. S. et al. What Should We Make with CO2 and How Can We Make It? Joule 2, 825832, doi:https://doi.org/10.1016/j.joule.2017.09.003 (2018). 
Garg, S. et al. Advances and challenges in electrochemical CO2 reduction processes: an engineering and design perspective looking beyond new catalyst materials. Journal of Materials Chemistry A 8, 1511-1544, doi:10.1039/C9TA13298H (2020).

24 Li, F., Chen, L., Knowles, G. P., MacFarlane, D. R. \& Zhang, J. Hierarchical Mesoporous SnO2 Nanosheets on Carbon Cloth: A Robust and Flexible Electrocatalyst for CO2 Reduction with High Efficiency and Selectivity. Angewandte Chemie International Edition 56, 505-509, doi:10.1002/anie.201608279 (2017).

25 Burdyny, T. \& Smith, W. A. CO2 reduction on gas-diffusion electrodes and why catalytic performance must be assessed at commercially-relevant conditions. Energy \& Environmental Science 12, 1442-1453, doi:10.1039/C8EE03134G (2019).

26 García de Arquer, F. P. et al. $\mathrm{CO}<\mathrm{sub}>2</$ sub $>$ electrolysis to multicarbon products at activities greater than 1 A cm<sup $>-2</$ sup $>$. Science 367, 661-666, doi:10.1126/science.aay4217 (2020).

27 Mahmood, M. N., Masheder, D. \& Harty, C. J. Use of gas-diffusion electrodes for high-rate electrochemical reduction of carbon dioxide. I. Reduction at lead, indium- and tin-impregnated electrodes. Journal of Applied Electrochemistry 17, 1159-1170, doi:10.1007/BF01023599 (1987).

28 Prakash, G. K. S., Viva, F. A. \& Olah, G. A. Electrochemical reduction of CO2 over Sn-Nafion ${ }^{\circledR}$ coated $^{2}$ electrode for a fuel-cell-like device. Journal of Power Sources 223, 68-73, doi:https://doi.org/10.1016/j.jpowsour.2012.09.036 (2013).

29 Nakagawa, S., Kudo, A., Azuma, M. \& Sakata, T. Effect of pressure on the electrochemical reduction of $\mathrm{CO} 2$ on Group VIII metal electrodes. Journal of Electroanalytical Chemistry and Interfacial Electrochemistry 308, 339-343, doi:https://doi.org/10.1016/0022-0728(91)85080-9 (1991).

30 Hara, K. Electrochemical Reduction of $\mathrm{CO}$ [sub 2] on a Cu Electrode under High Pressure. Journal of The Electrochemical Society 141, 2097, doi:10.1149/1.2055067 (1994).

31 Pardal, T. et al. Syngas production by electrochemical $\mathrm{CO} 2$ reduction in an ionic liquid basedelectrolyte. Journal of CO2 Utilization 18, 62-72, doi:https://doi.org/10.1016/j.jcou.2017.01.007 (2017).

32 Figueiredo, M. C., Ledezma-Yanez, I. \& Koper, M. T. M. In Situ Spectroscopic Study of CO2 Electroreduction at Copper Electrodes in Acetonitrile. ACS Catalysis 6, 2382-2392, doi:10.1021/acscatal.5b02543 (2016).

33 Lobaccaro, P. et al. Effects of temperature and gas-liquid mass transfer on the operation of small electrochemical cells for the quantitative evaluation of $\mathrm{CO} 2$ reduction electrocatalysts. Physical Chemistry Chemical Physics 18, 26777-26785, doi:10.1039/C6CP05287H (2016).

34 Abu-Zahra, M. R. M., Niederer, J. P. M., Feron, P. H. M. \& Versteeg, G. F. CO2 capture from power plants: Part II. A parametric study of the economical performance based on mono-ethanolamine. International Journal of Greenhouse Gas Control 1, 135-142, doi:https://doi.org/10.1016/S17505836(07)00032-1 (2007).

35 Chowdhury, F. A., Yamada, H., Higashii, T., Goto, K. \& Onoda, M. CO2 Capture by Tertiary Amine Absorbents: A Performance Comparison Study. Industrial \& Engineering Chemistry Research 52, 8323-8331, doi:10.1021/ie400825u (2013).

36 Jens, C. M., Müller, L., Leonhard, K. \& Bardow, A. To Integrate or Not to Integrate-TechnoEconomic and Life Cycle Assessment of $\mathrm{CO} 2$ Capture and Conversion to Methyl Formate Using Methanol. ACS Sustainable Chemistry \& Engineering 7, 12270-12280, doi:10.1021/acssuschemeng.9b01603 (2019).

37 Chen, L. et al. Electrochemical Reduction of Carbon Dioxide in a Monoethanolamine Capture Medium. ChemSusChem 10, 4109-4118, doi:doi:10.1002/cssc.201701075 (2017).

38 Diaz, L. A. et al. Electrochemical production of syngas from $\mathrm{CO} 2$ captured in switchable polarity solvents. Green Chemistry 20, 620-626, doi:10.1039/C7GC03069J (2018). 
39 Bernhardsen, I. M. \& Knuutila, H. K. A review of potential amine solvents for CO2 absorption process: Absorption capacity, cyclic capacity and pKa. International Journal of Greenhouse Gas Control 61, 27-48, doi:https://doi.org/10.1016/j.ijggc.2017.03.021 (2017).

40 Barzagli, F., Lai, S. \& Mani, F. Novel non-aqueous amine solvents for reversible CO2 capture. Energy Procedia 63, 1795-1804, doi:https://doi.org/10.1016/j.egypro.2014.11.186 (2014).

41 Alvarez-Guerra, M., Del Castillo, A. \& Irabien, A. Continuous electrochemical reduction of carbon dioxide into formate using a tin cathode: Comparison with lead cathode. Chemical Engineering Research and Design 92, 692-701, doi:https://doi.org/10.1016/j.cherd.2013.11.002 (2014).

42 Li, M.-H. \& Chang, B.-C. Solubilities of Carbon Dioxide in Water + Monoethanolamine + 2-Amino2-methyl-1-propanol. Journal of Chemical \& Engineering Data 39, 448-452, doi:10.1021/je00015a010 (1994).

43 Santos, P. S., Gomes, F. J. \& Bordado, C. J. Scale-Up Effects of CO2 Capture by Methyldiethanolamine (MDEA) Solutions in Terms of Loading Capacity. Technologies 4, doi:10.3390/technologies4030019 (2016).

44 Han, B., Steen, S. M., Mo, J. \& Zhang, F.-Y. Electrochemical performance modeling of a proton exchange membrane electrolyzer cell for hydrogen energy. International Journal of Hydrogen Energy 40, 7006-7016, doi:https://doi.org/10.1016/j.ijhydene.2015.03.164 (2015).

45 Zhu, W. et al. Monodisperse Au Nanoparticles for Selective Electrocatalytic Reduction of CO2 to CO. Journal of the American Chemical Society 135, 16833-16836, doi:10.1021/ja409445p (2013). 
Figures

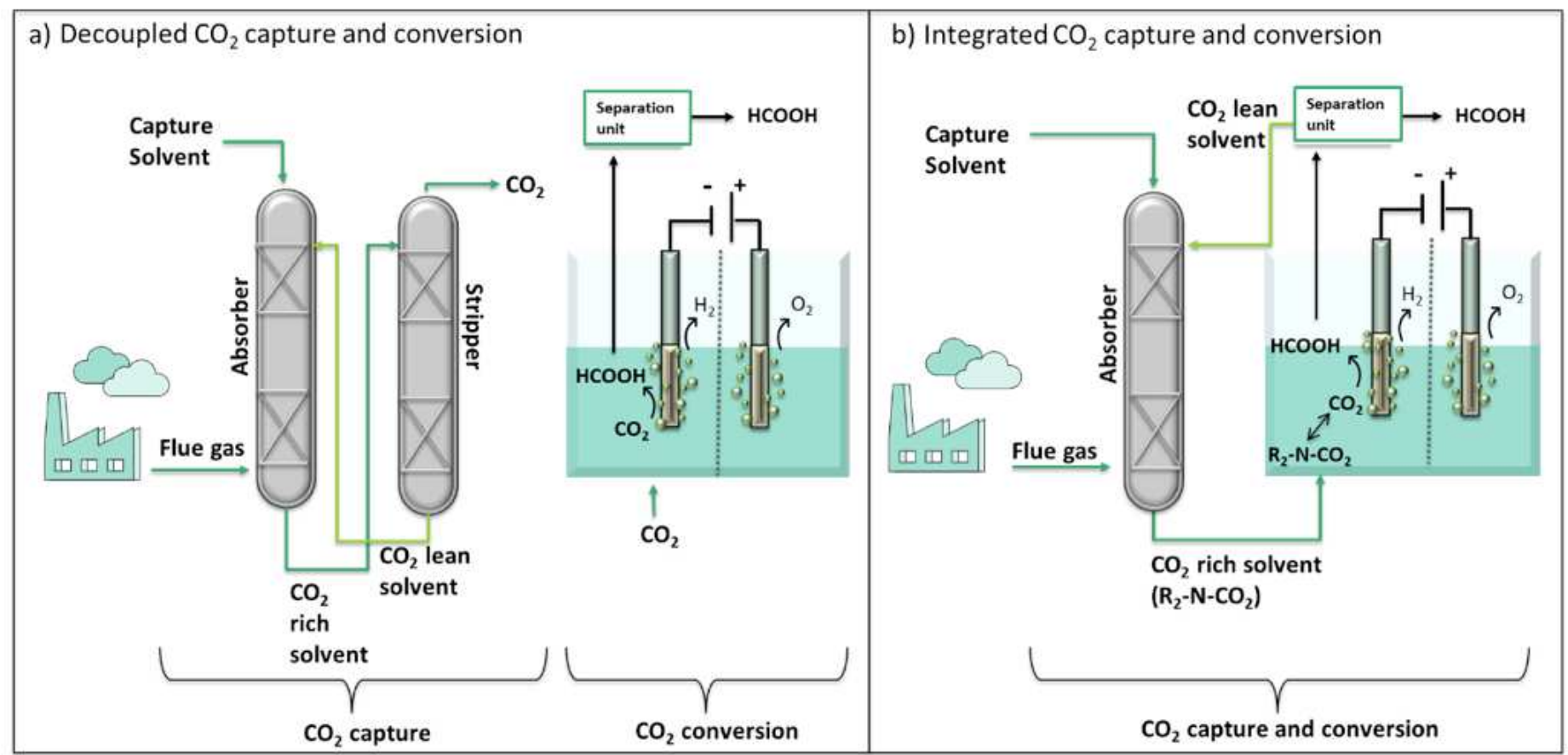

Figure 1

Schematic representation of the two possible routes for $\mathrm{CO} 2$ capture and utilization (CCU) technologies. a) Decoupled CO2 capture and conversion and b) Proposed integrated CO2 capture and conversion, where R2-N-CO2 stands for absorbed $\mathrm{CO} 2$ in an amine solution as a carbamate/bicarbonate form. 


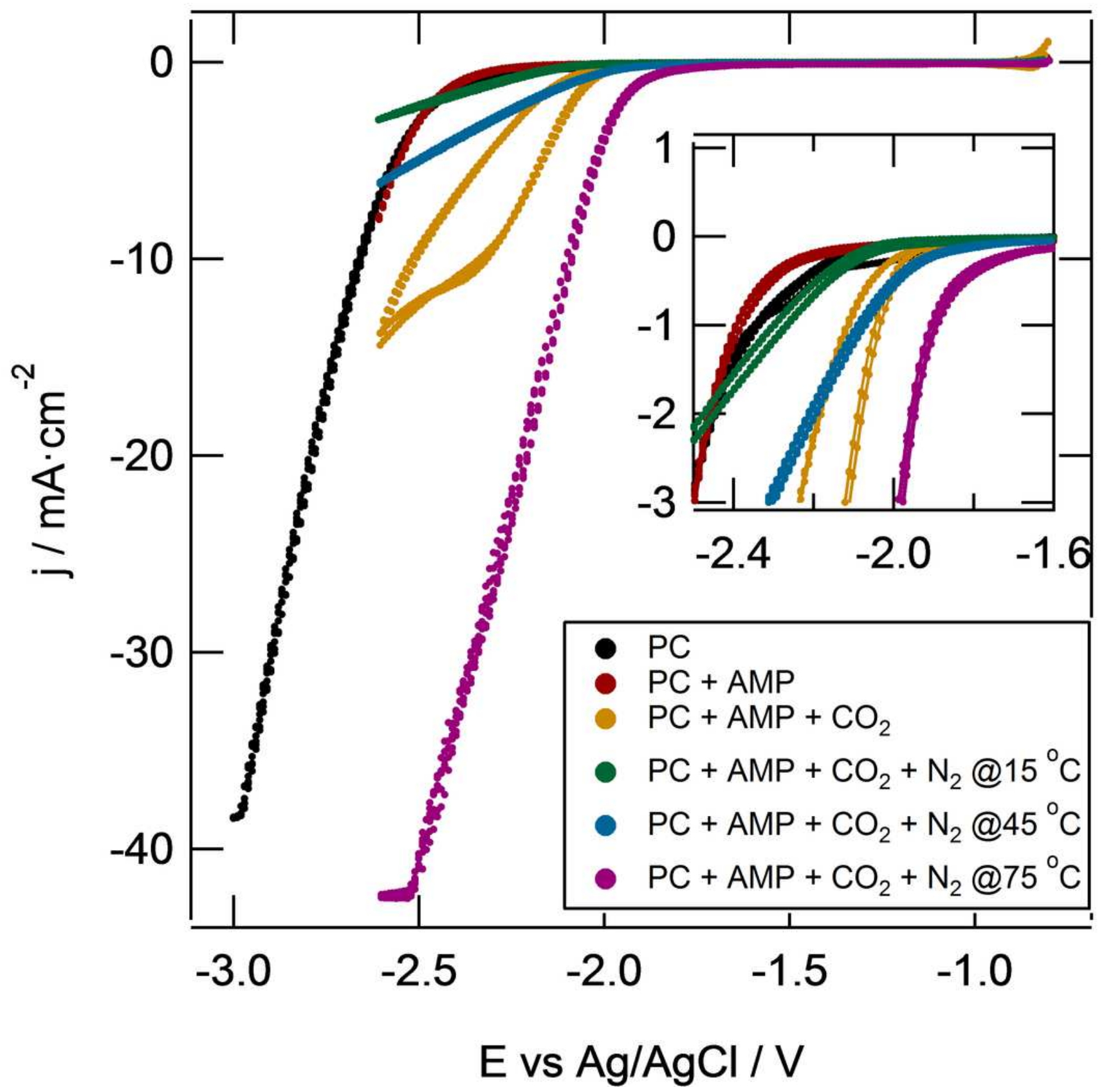

Figure 2

Cyclic voltammograms of $\mathrm{Pb}$ electrode in a $0.7 \mathrm{M} \mathrm{TEACl}$ in propylene carbonate solution in the absence of 2-amino-2-methyl-1-propanol (AMP) (black line), in the presence of $1 \mathrm{M} \mathrm{AMP} \mathrm{(red} \mathrm{line),} \mathrm{in} \mathrm{the} \mathrm{presence}$ of $\mathrm{CO} 2$ captured at 1 bar and $15^{\circ} \mathrm{C}$ in $1 \mathrm{M} \mathrm{AMP}$ (yellow line), in the presence of CO2 captured in $1 \mathrm{M} \mathrm{AMP}$ after removal of free $\mathrm{CO} 2$ with $\mathrm{N} 2$ and at $15^{\circ} \mathrm{C}$ (green line), in the presence of $\mathrm{CO} 2$ captured in $1 \mathrm{M} \mathrm{AMP}$ after removal of free $\mathrm{CO} 2$ with $\mathrm{N} 2$ and at $45^{\circ} \mathrm{C}$ (blue line) and in the presence of $\mathrm{CO} 2$ captured in $1 \mathrm{M}$ AMP after removal of free $\mathrm{CO} 2$ with $\mathrm{N} 2$ and at $75^{\circ} \mathrm{C}$ (purple line). Inset displays a zoom in between $-1.6 \mathrm{~V}$ and $-2.5 \mathrm{~V}$ vs $\mathrm{Ag} / \mathrm{AgCl}$. 
a)

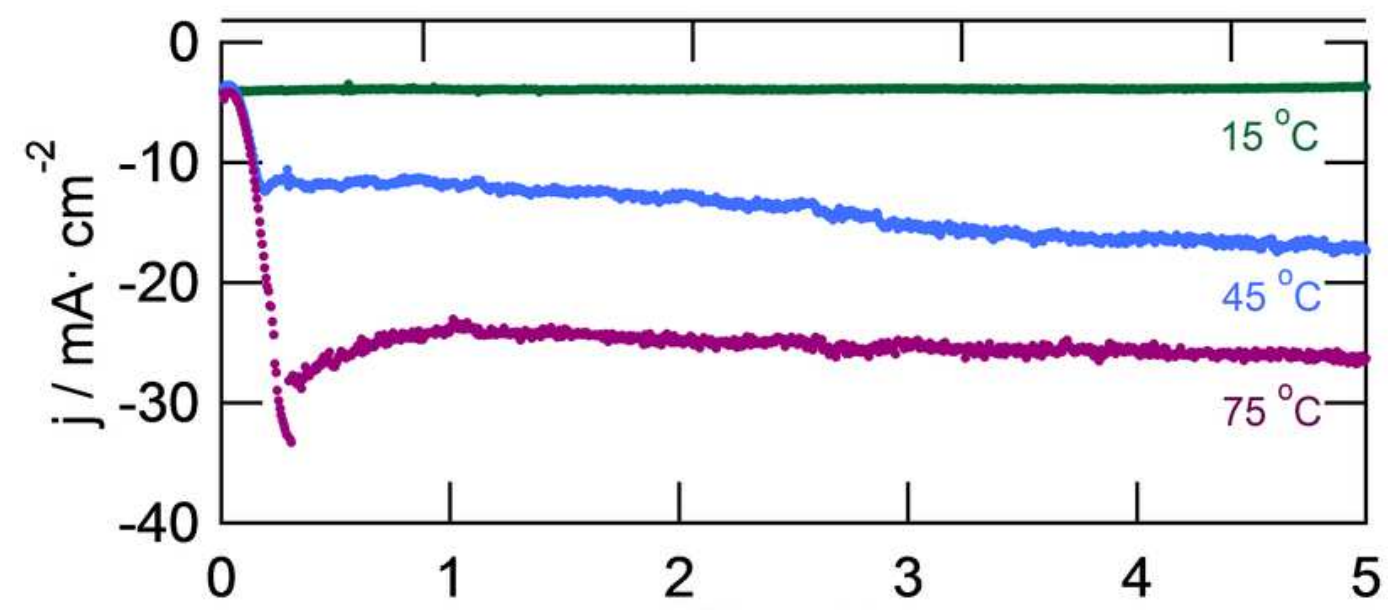

$\bar{\top}$

b)

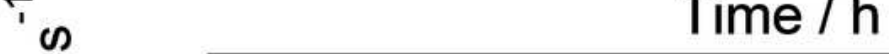

c)

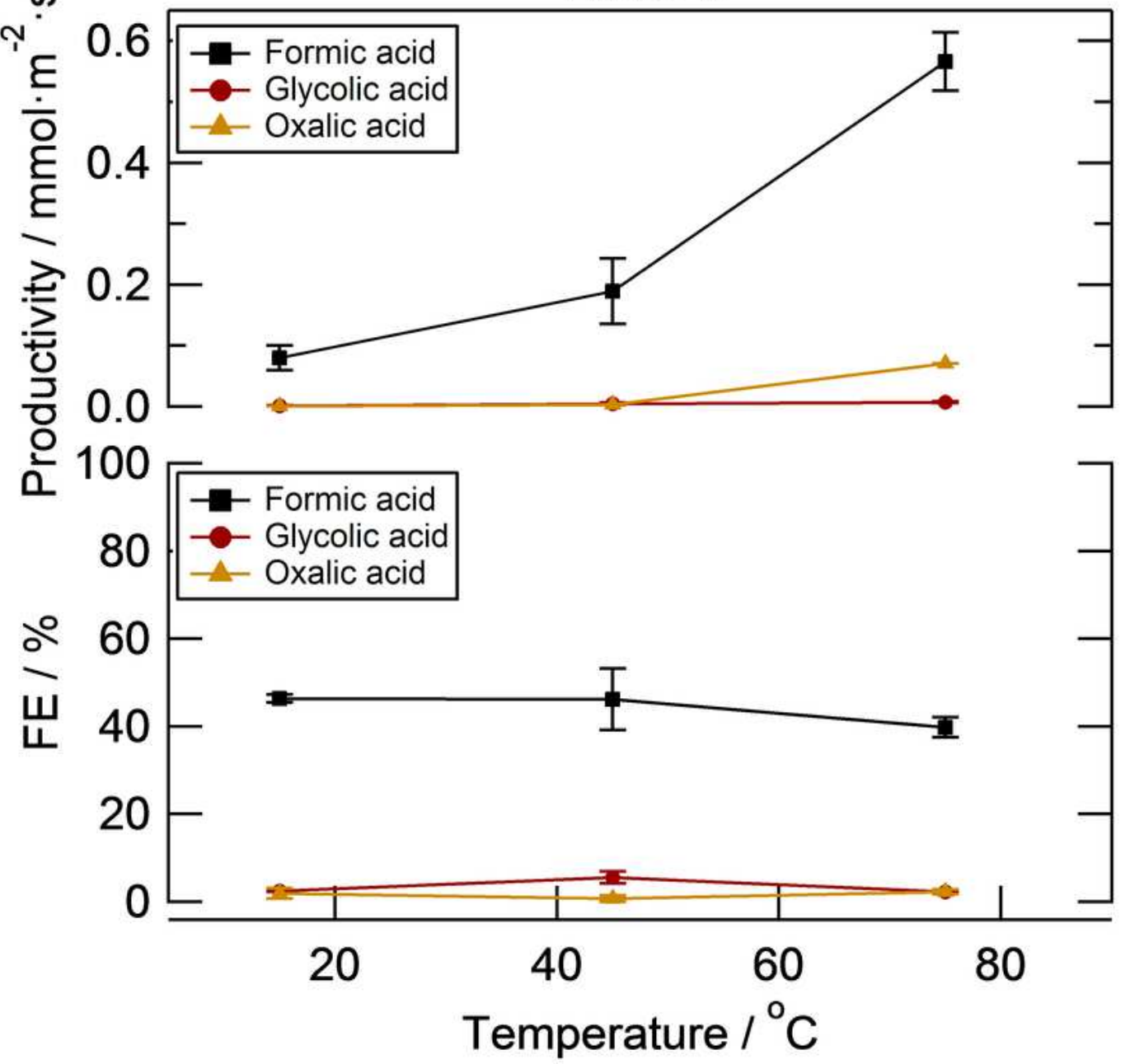

Figure 3

a) Chronoamperometry at $-2.5 \mathrm{~V}$ vs $\mathrm{Ag} / \mathrm{AgCl}$ on $\mathrm{Pb}$ electrode in a $0.7 \mathrm{M} \mathrm{TEACl}$ in PC solution containing $1 \mathrm{M}$ AMP preloaded with $\mathrm{CO} 2$ as a function of time at different temperatures $\left(15,45\right.$ and $\left.75^{\circ} \mathrm{C}\right)$. b) Productivity of formic acid, glycolic acid and oxalic acid as a function of the temperature during electrolysis at $-2.5 \mathrm{~V}$ vs Ag/ $\mathrm{AgCl}$. c) Average faradaic efficiency during electrolysis at $-2.5 \mathrm{~V} \mathrm{vs} \mathrm{Ag/AgCl}$ of formic acid, glycolic acid and oxalic acid as a function of the temperature. 


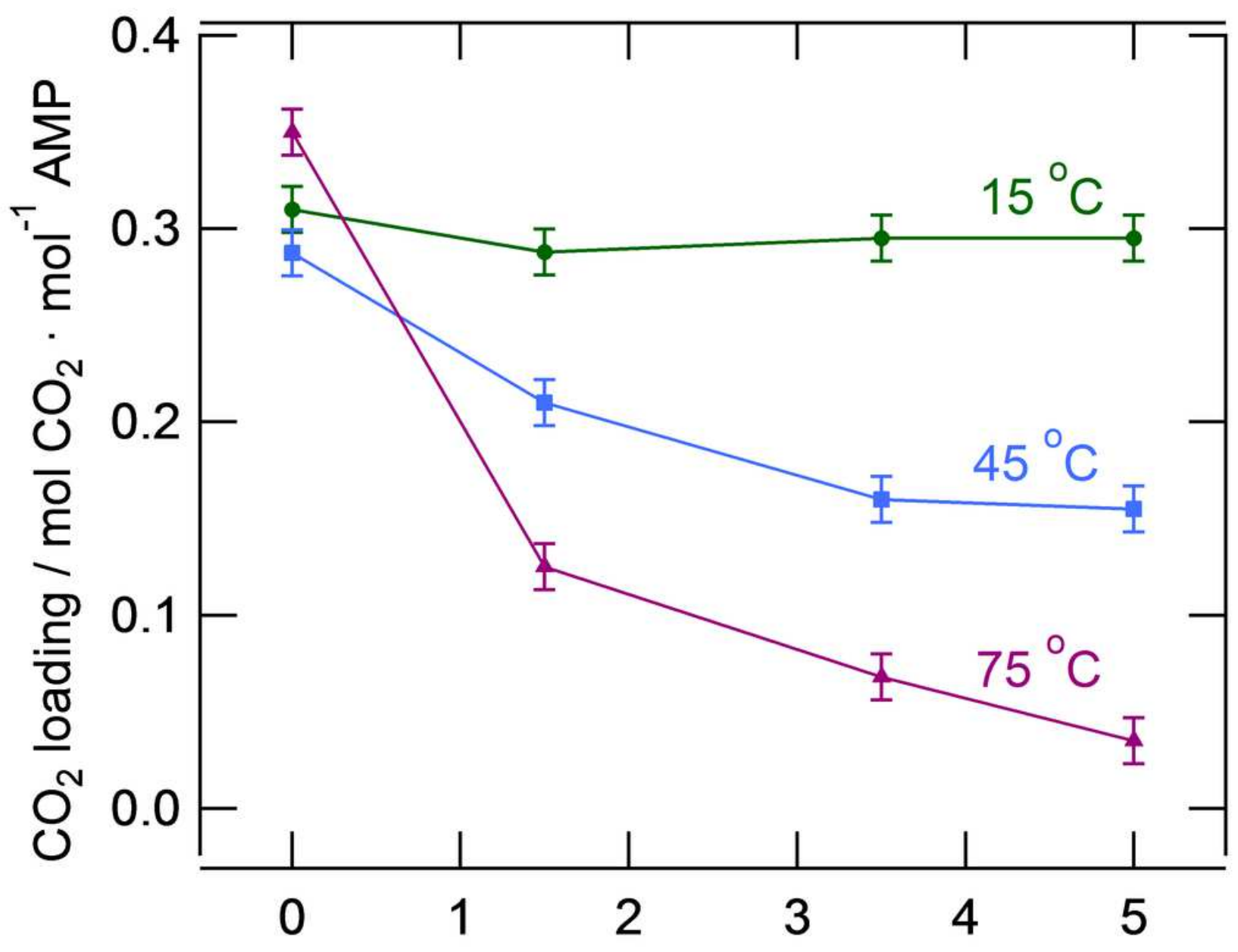

Time / h

Figure 4

CO2 loading measured during electrolysis at $-2.5 \mathrm{~V}$ vs $\mathrm{Ag} / \mathrm{AgCl}$ on $\mathrm{Pb}$ electrode in a $0.7 \mathrm{M} \mathrm{TEACl}$ in PC solution containing $1 \mathrm{M}$ AMP preloaded with $\mathrm{CO} 2$ as a function of time at different temperatures $(15,45$ and $75^{\circ} \mathrm{C}$ ) as a function of time. $\mathrm{CO} 2$ loading refers to all the $\mathrm{CO} 2$ loading species including carbamates and bicarbonates. 
a)

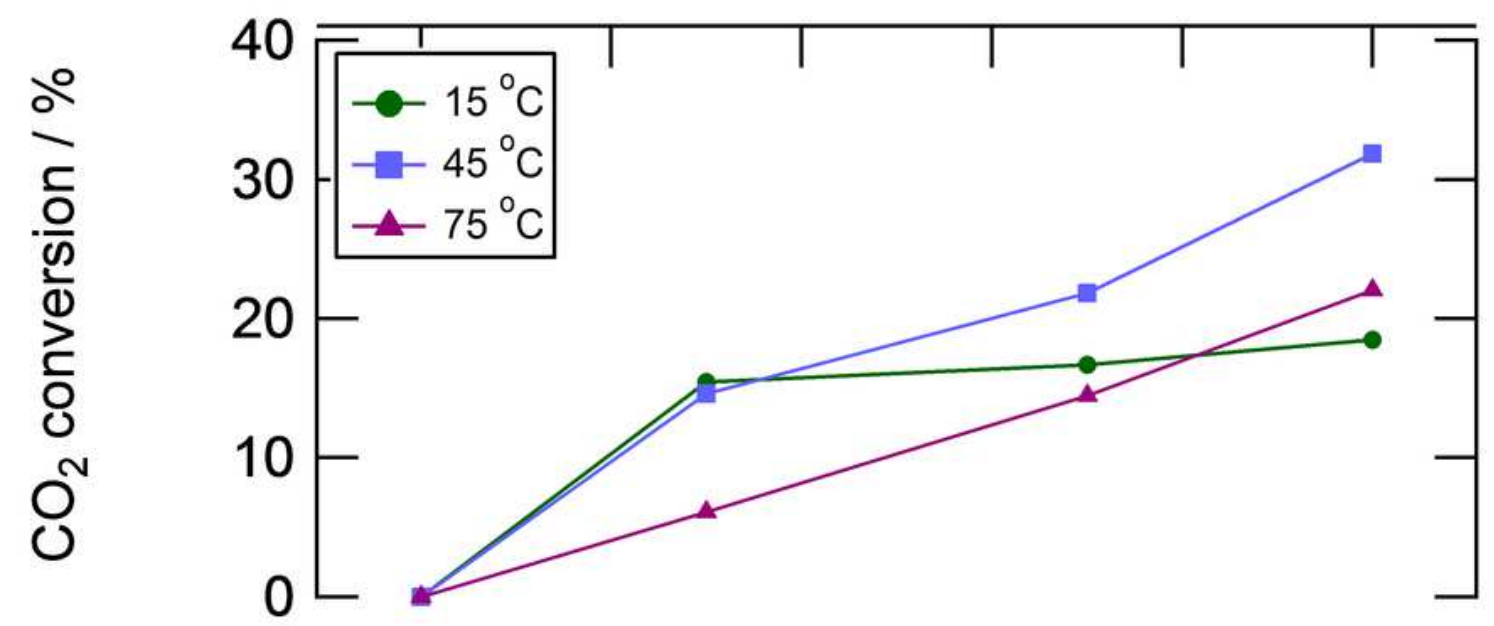

b)
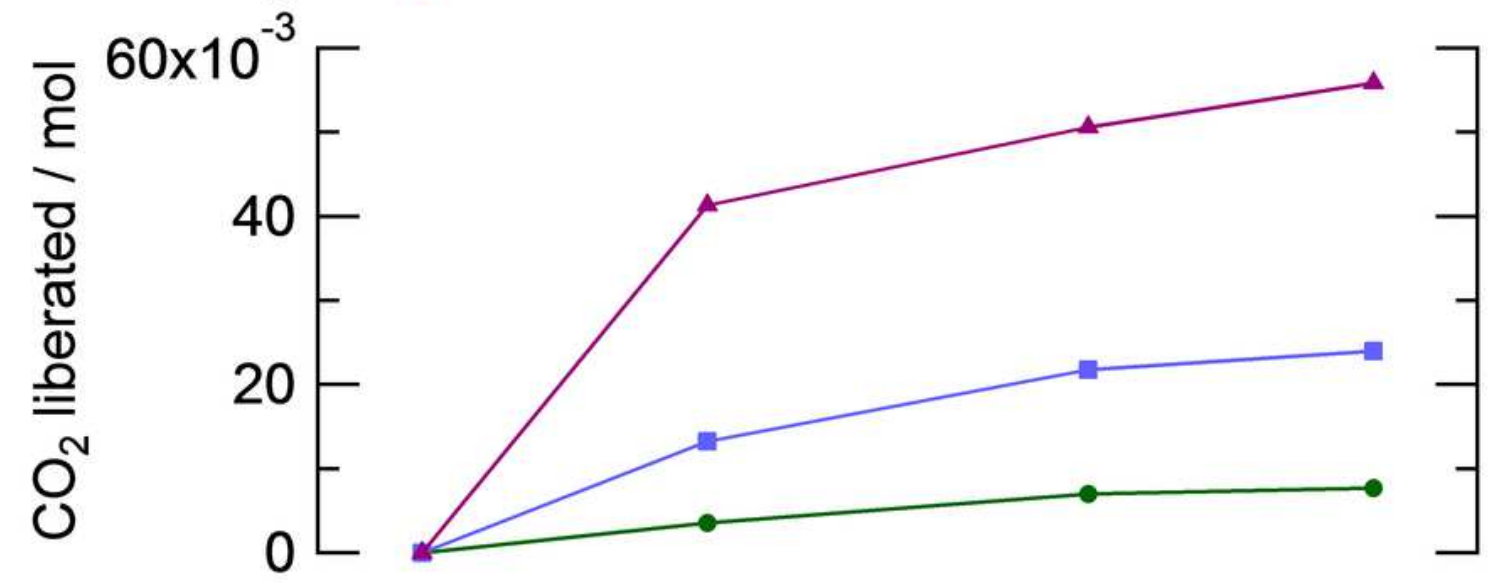

c)

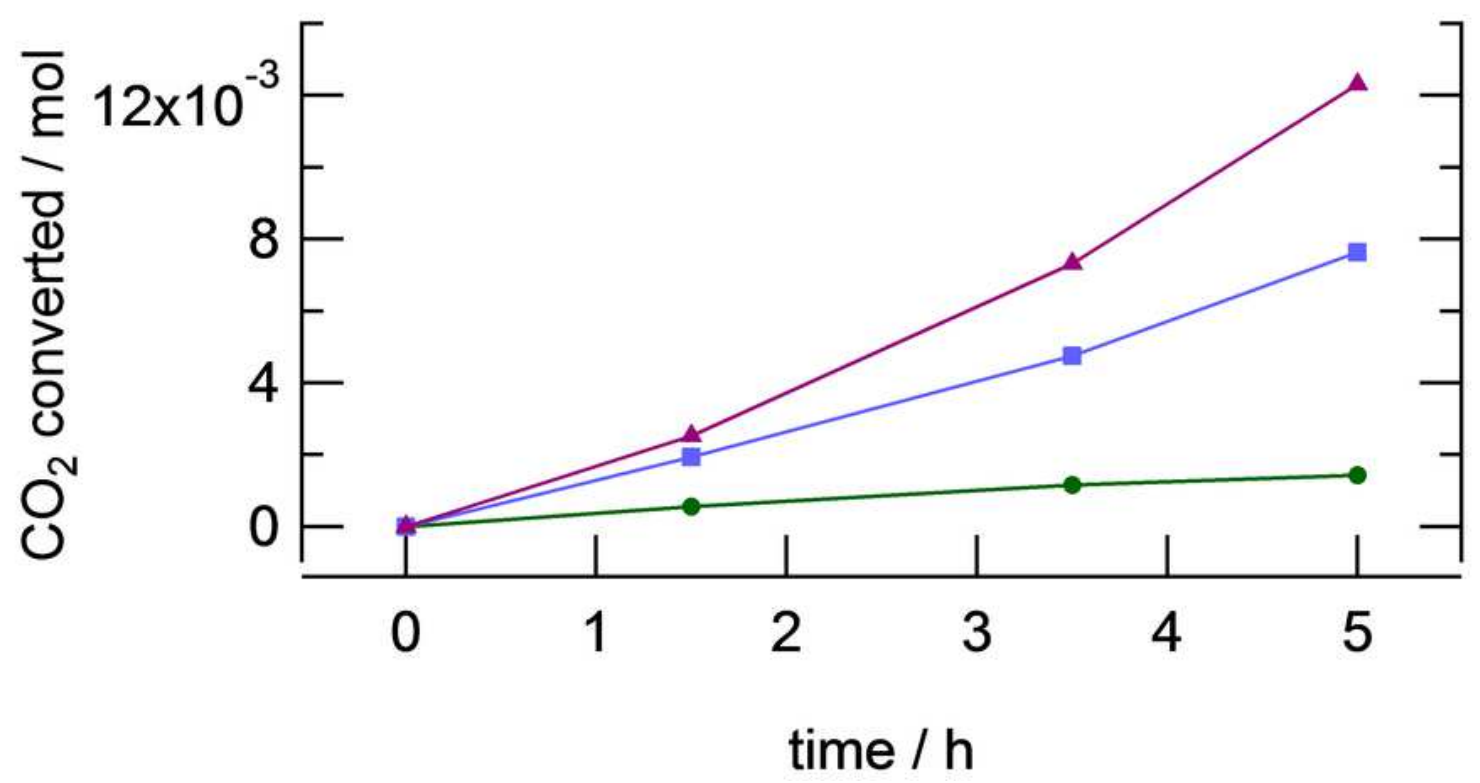

Figure 5

a) $\mathrm{CO} 2$ conversion on a $\mathrm{Pb}$ electrode in a $1 \mathrm{M} \mathrm{AMP}$ in PC solution as a function of time and temperature, b) Moles of $\mathrm{CO} 2$ liberated from a $1 \mathrm{M}$ AMP in PC solution as a function of time and temperature, c) Moles of $\mathrm{CO} 2$ converted on a Pb electrode in a 1M AMP in PC solution as a function of time and temperature. 
a)

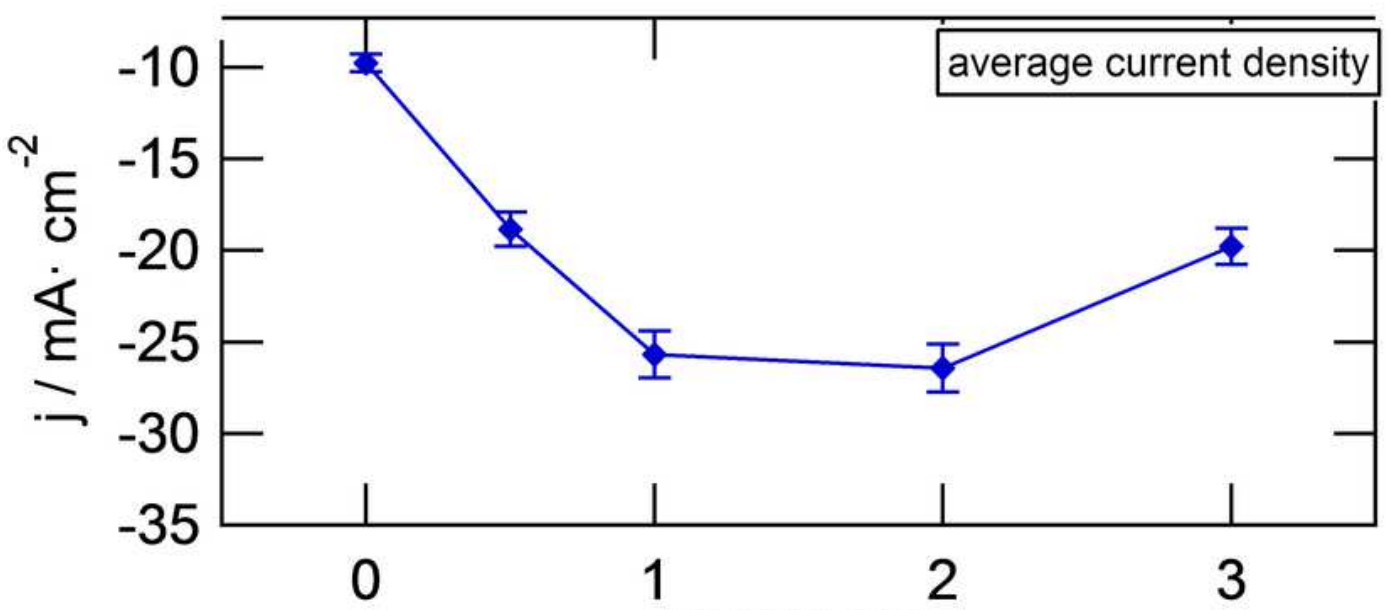

b)

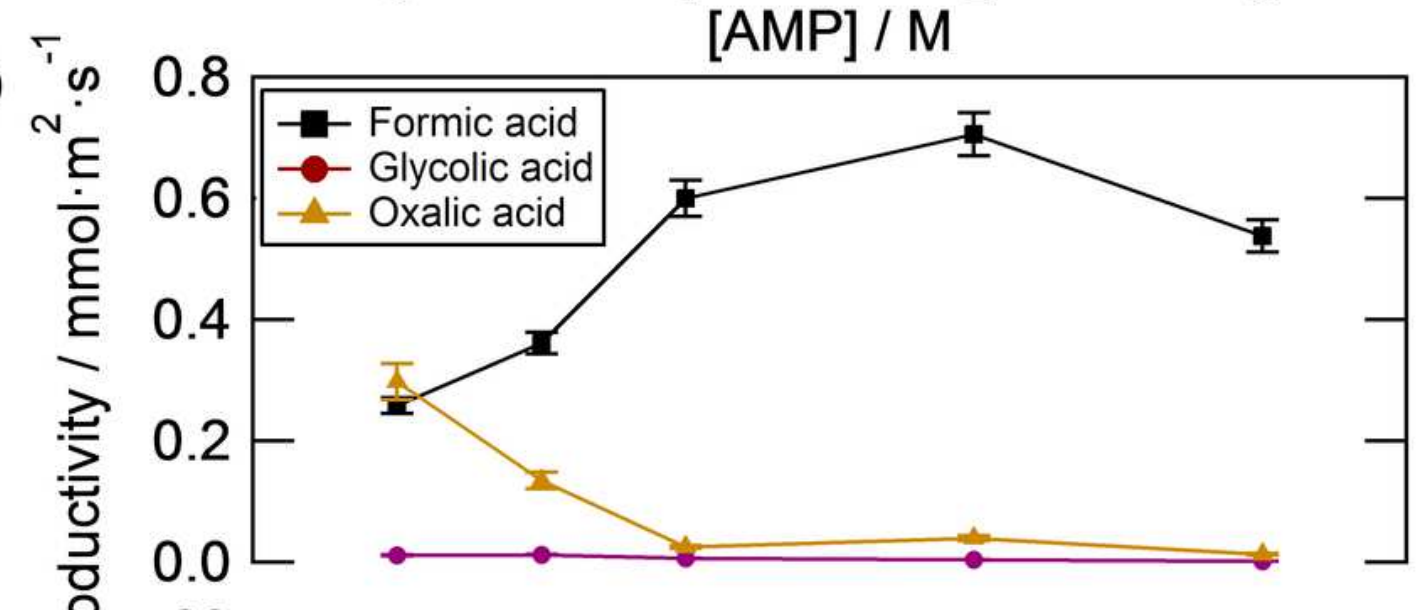

c)

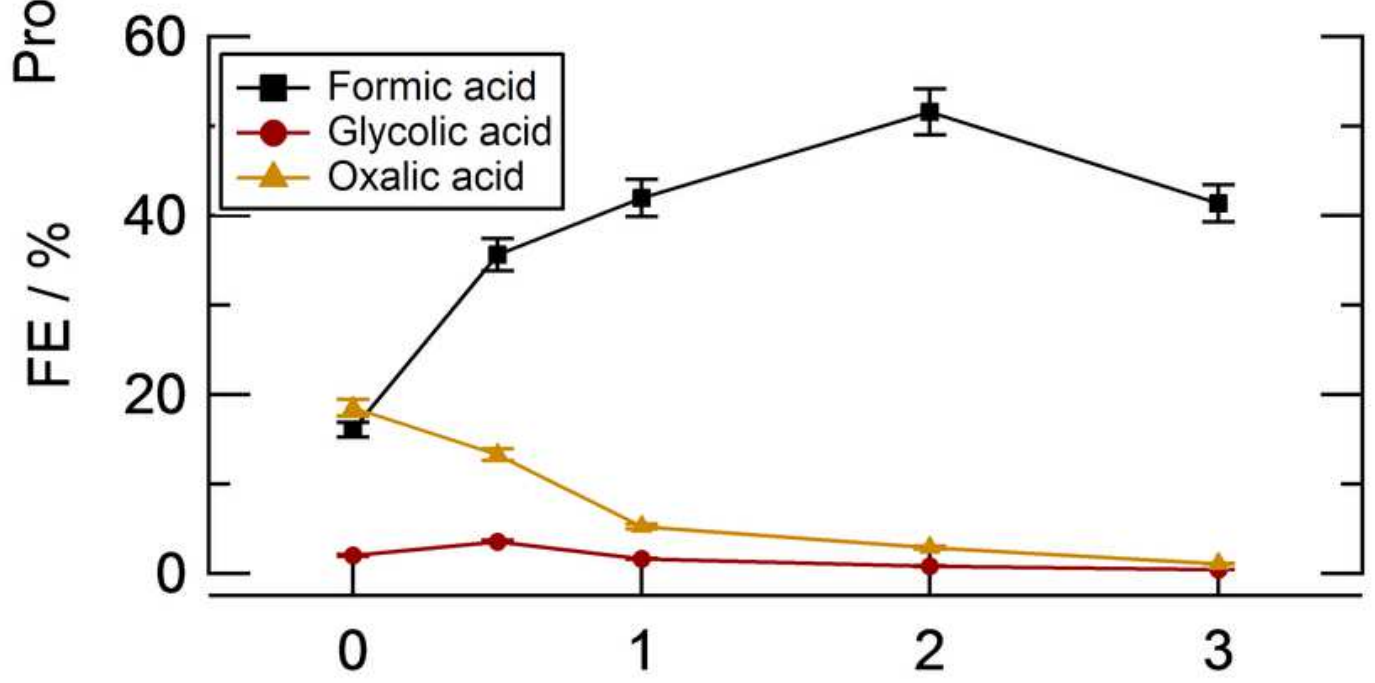

$[\mathrm{AMP}] / \mathrm{M}$

Figure 6

a) Average current density measured over 5 hours of electrolysis at $-2.5 \mathrm{~V}$ vs $\mathrm{Ag} / \mathrm{AgCl}$ at $75^{\circ} \mathrm{C}$ on $\mathrm{Pb}$ electrode in a $\mathrm{CO} 2$ preloaded $0.7 \mathrm{M} \mathrm{TEACl}$ in PC solution containing different concentrations of AMP ( 0 , $0.5,1,2$ and $3 \mathrm{M}$ ). b) Productivity of formic acid, glycolic acid and oxalic acid as a function of the concentration of AMP during electrolysis at $-2.5 \mathrm{~V}$ vs $\mathrm{Ag} / \mathrm{AgCl}$ at $75^{\circ} \mathrm{C}$. c) Average faradaic efficiency 
during electrolysis at $-2.5 \mathrm{~V}$ vs. $\mathrm{Ag} / \mathrm{AgCl}$ at $75{ }^{\circ} \mathrm{C}$ of formic acid, glycolic acid and oxalic acid as a function of the concentration of AMP.

a)

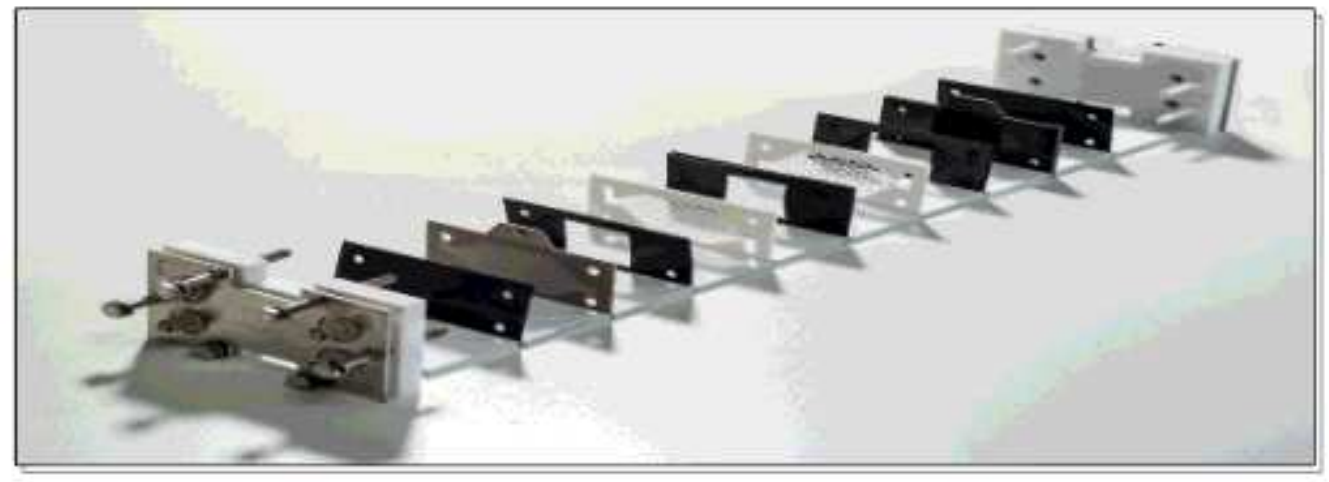

b)

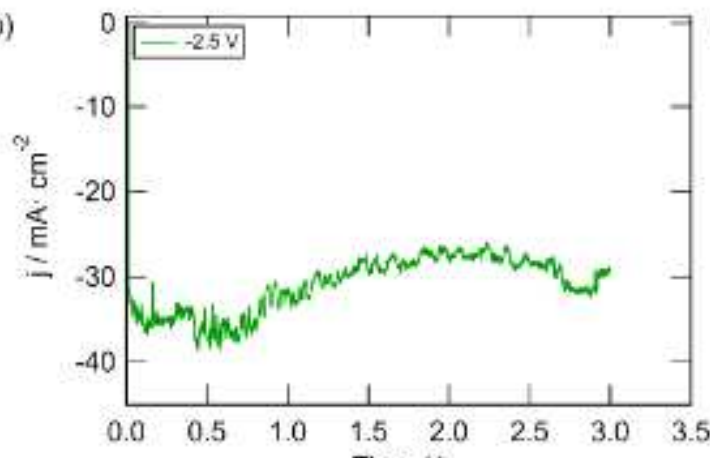

c)

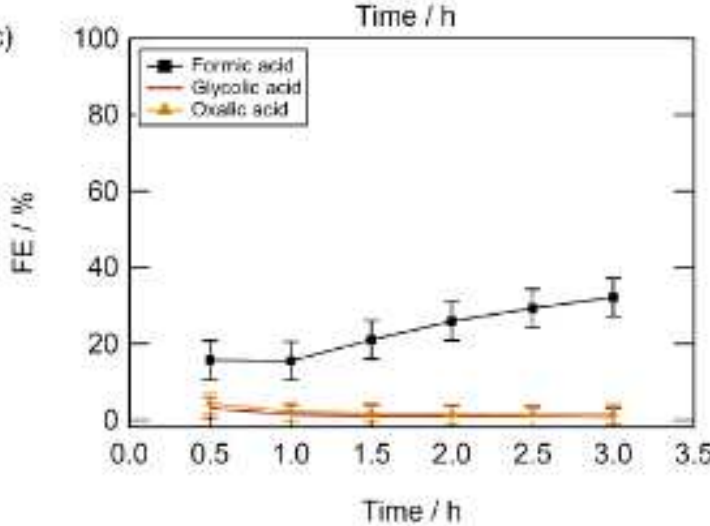

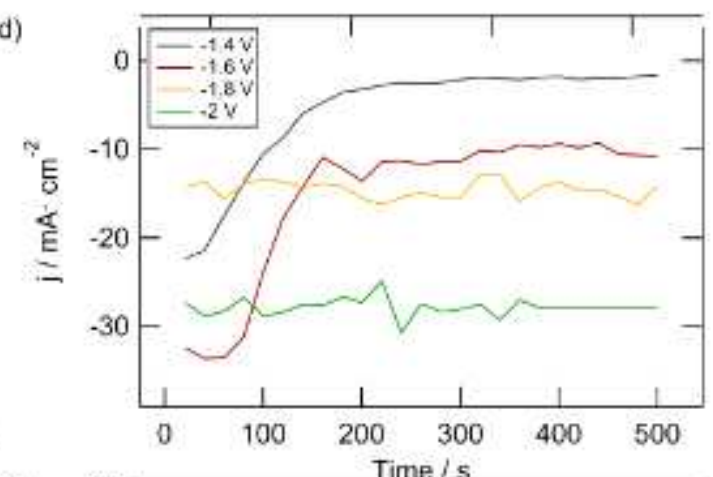

e)

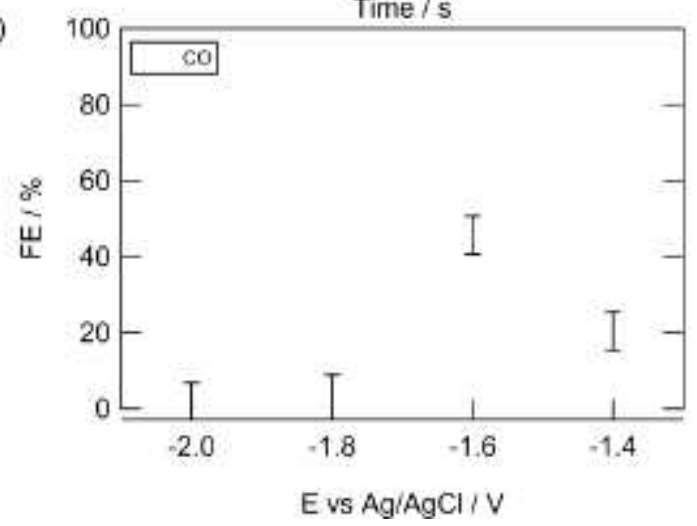

\section{Figure 7}

a) Electrochemical flow cell employed for $\mathrm{CO} 2$ conversion electrolysis on $\mathrm{Pb}$ electrodes (b and c) and on Au electrodes ( $d$ and e). b) current density and c) Faradaic efficiency towards formic acid, glycolic acid and oxalic acid measured during electrolysis at $75^{\circ} \mathrm{C}$ on $\mathrm{Pb}$ electrode at $-2.5 \mathrm{~V}$ vs $\mathrm{Ag} / \mathrm{AgCl}$ in a $1 \mathrm{M} \mathrm{AMP}$ in $\mathrm{PC}$, preloaded with $\mathrm{CO} 2$. d) current density and e) Faradaic efficiency towards $\mathrm{CO}$ measured during electrolysis on Au electrode at $-1.4,-1.6,-1.8$ and $-2 \mathrm{~V} v \mathrm{vg} / \mathrm{AgCl}$ in a $1 \mathrm{M} \mathrm{AMP}$ in $\mathrm{PC}$, preloaded with $\mathrm{CO} 2$.

\section{Supplementary Files}

This is a list of supplementary files associated with this preprint. Click to download.

- SupportinginformationIntegratedCO2captureandconversionusingaminebasedsolvents.docx 